CLAUDIA KIYOMI MINAZAKI

Imunolocalização dos receptores de ocitocina no testículo e epidídimo de cães

São Paulo

2013 
CLAUDIA KIYOMI MINAZAKI

\section{Imunolocalização dos receptores de ocitocina no testículo e epidídimo de cães}

Tese apresentada ao Programa de PósGraduação em Reprodução Animal da Faculdade de Medicina Veterinária e Zootecnia da Universidade de São Paulo para obtenção do título de Doutor em Ciências

Departamento:

Reprodução Animal

Área de concentração:

Reprodução Animal

Orientador:

Profa. Dra. Valquiria Hyppólito Barnabe

São Paulo 
Autorizo a reprodução parcial ou total desta obra, para fins acadêmicos, desde que citada a fonte.

DADOS INTERNACIONAIS DE CATALOGAÇÃO-NA-PUBLICAÇÃO

(Biblioteca Virginie Buff D’Ápice da Faculdade de Medicina Veterinária e Zootecnia da Universidade de São Paulo)

T.2775 Minazaki, Claudia Kiyomi

FMVZ Imunolocalização dos receptores de ocitocina no testículo e epidídimo de cães / Claudia Kiyomi Minazaki. -- 2013

$51 \mathrm{f}$ : : il.

Tese (Doutorado) - Universidade de São Paulo. Faculdade de Medicina Veterinária e Zootecnia. Departamento de Reprodução Animal, São Paulo, 2013.

Programa de Pós-Graduação: Reprodução Animal.

Área de concentração: Reprodução Animal.

Orientador: Profa. Dra. Valquiria Hyppólito Barnabe.

1. Ocitocina. 2. Receptor de ocitocina. 3. Infertilidade. I. Título. 


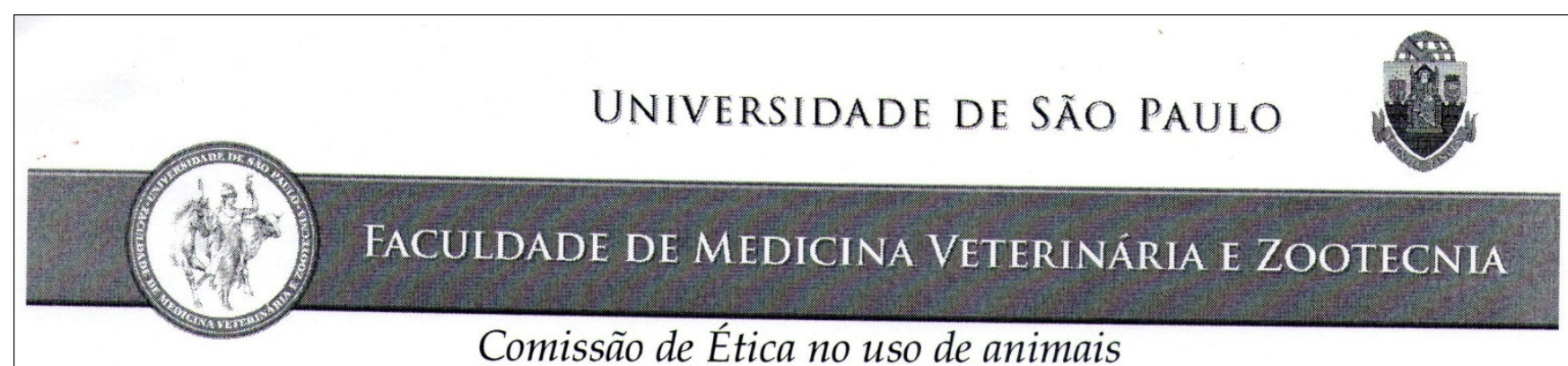

Comissão de Ética no uso de animais

\section{CERTIFICADO}

Certificamos que o Projeto intitulado "Imunolocalização do receptor de ocitocina (OTR) no epidídimo e testículo de cães", protocolado sob o n ${ }^{\circ} 1912 / 2010$, utilizando 30 (trinta) cães, sob a responsabilidade da Profa. Dra. Valquíria Hyppólito Barnabé, está de acordo com os princípios éticos de experimentação animal da "Comissão de Ética no uso de animais" da Faculdade de Medicina Veterinária e Zootecnia da Universidade de São Paulo e foi aprovado em reunião de $07 / 04 / 2010$.

We certify that the Research "Immunolocalization oh the oxytocin receptor (OTR) in the epididymis and testis of dogs", protocol number 1912/2010, utilizing 30 (thirty) dogs, under the responsibility Profa. Dra. Valquíria Hyppólito Barnabé, agree with Ethical Principles in Animal Research adopted by "Ethic Committee in the use of animals" of the School of Veterinary Medicine and Animal Science of University of São Paulo and was approved in the meeting of day 04/07/2010.

São Paulo, 08 de abril de 2010

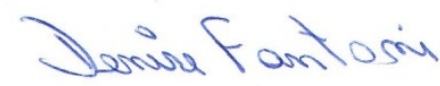

Profa. Dra. Denise Tabacchi Fantoni

Presidente 


\section{FOLHA DE AVALIAÇÃO}

Autor: MINAZAKI, Cláudia Kiyomi

Título: Imunolocalização dos receptores de ocitocina no testículo e epidídimo de cães

Tese apresentada ao Programa de Pós-Graduação em Reprodução Animal da Faculdade de Medicina Veterinária e Zootecnia da Universidade de São Paulo para a obtenção do título de Doutor em Ciências

Data:

\section{Banca Examinadora}

Prof. Dr.

Instituição:

Julgamento:

Prof. Dr.

Instituição:

Julgamento:

Prof. Dr.

Instituição:

Julgamento:

Prof. Dr.

Instituição:

Julgamento:

Prof. Dr.

Instituição:

Julgamento: 


\section{DEDICATÓRIA}

Dedico este trabalho a minha família que esteve sempre presente em todos os momentos e compartilharam de todas as minhas conquistas durante este doutorado. A meus pais Takeshi e Toshie, minhas irmãs Cristina, Célia, Ana Márcia, meus cunhados Carlos Pereira, Ricardo e Carlos Gennari, meus sobrinhos Rafael, Liliana, Ana Beatriz e Gustavo sinceros agradecimentos por todo apoio. 


\section{AGRADECIMENTOS}

Agradeço em especial aos professores Valquiria Barnabé e Renato Barnabé que acreditaram no meu trabalho e que foram como pais, amigos e conselheiros durante esta jornada do doutorado. Aprendi muito com a experiência de vocês e com certeza todo este carinho com que fui recebida em seu laboratório levarei para sempre como uma lembrança em minha vida.

Agradeço as professoras Maria Inês Borella e Estela M.F. Bevilacqua do departamento de Biologia Celular e do Desenvolvimento que me receberam com as portas abertas e me apoiaram muito em meus experimentos transmitindo todos os conhecimentos que me permitiram dar continuidade ao projeto.

Um agradecimento muito especial aos meus fiéis amigos e companheiros Andressa Dalmazzo pelo apoio e ajuda em todos os momentos deste doutorado, Harumi, Silvia Crusco, Sandra Penteado, Líria Okuda, Reinaldo Orsi que além de auxiliarem no projeto suportaram com muito humor e paciência meus momentos difíceis nesta trajetória.

Aos amigos Chayrra, Lázaro, Cruz, Carla, Rose que me auxiliaram em meus experimentos e sempre estiveram presentes ao meu lado.

Aos colegas do laboratório de andrologia Marcílio, Diego, Paola, Carla, Eduardo que pude conviver neste período um carinho especial.

Muito obrigada a todos!! 


\section{RESUMO}

MINAZAKI, C. K. Imunolocalização dos receptores de ocitocina no testículo e epidídimo de cães. [Oxytocin receptors (OTR) immunolocation in testicles and epidydimis in dogs]. 2013. 51F. Tese (Doutorado em Ciências) - Faculdade de Medicina Veterinária e Zootecnia, Universidade de São Paulo, São Paulo, 2013.

A expressão dos receptores da ocitocina (OTR) em machos, embora estudada em algumas espécies, não foi ainda estabelecida em cães. O objetivo deste estudo foi trazer novas perspectivas para a utilização terapêutica da ocitocina (OT) em patologias reprodutivas em cães já que tem sido utilizada no tratamento da infertilidade em homens. Foi realizada a imunolocalização dos receptores de OTR em amostras de testículo e epidídimo de cães coletadas por cirurgia eletiva de orquiectomia e fixadas em formaldeído tamponado a 10\%. Seguiu-se o processamento histológico de rotina, desparafinização, desidratação e recuperação de sítios antigênicos. A incubação foi feita com o anticorpo primário anti-OTR humano policlonal produzido em coelho e o polímero NOVOLINK da Nichereiß. A imunomarcação foi observada nas células mioepiteliais, células da musculatura lisa do estroma e nas células de Leydig no testículo e muito mais intensa nas células da musculatura lisa da região do epidídimo. A expressão dos OTR demonstrou-se maior no epidídimo quando comparada ao testículo. A distribuição dos OTR na imunomarcação e no western blotting reforçam os dados da literatura que sugerem ação da ocitocina no estímulo da contratilidade dos túbulos seminíferos e epidídimo, assim como seu papel na modulação dos níveis de androgênios nestes tecidos estimulando a conversão da testosterona em diidrotestosterona (DHT). Nossos resultados corroboram com a literatura permitindo que o conhecimento da distribuição das OTR no testículo e epidídimo de cães possibilite a utilização terapêutica da ocitocina e novas perspectivas para a área de reprodução e biotecnologia de cães.

Palavras chave: Ocitocina. Receptor de ocitocina. Infertilidade. 


\begin{abstract}
MINAZAKI, C. K. Oxytocin receptors (OTR) immunolocation in testicles and epidydimis in dog. [Imunolocalização dos receptores de ocitocina no testículo e epidídimo de cães]. 2013. 51F. Tese (Doutorado em Ciências) - Faculdade de Medicina Veterinária e Zootecnia, Universidade de São Paulo, São Paulo, 2013.
\end{abstract}

The expression of oxytocin receptors (OTR) in the male reproductive tract has been studied in several species with the exception of the dogs. In men, oxytocin (OT) therapy has been successfully used to treat infertility. Therefore, the aim of the present study was to provide new perspectives for the therapeutic use of oxytocin (OT) in reproductive disorders in dogs. We performed the immunolocalization of OTR in samples of testis and epididymides of dogs collected by elective orchiectomy and fixed in $10 \%$ buffered formaldehyde. This was followed by routine histological processing, deparaffinization, dehydration and recovery of antigenic sites. Incubation was performed with the human polyclonal anti-OTR primary antibody produced in rabbits and the NOVOLINK polymer (Nichirei, Japan). Oxytocin receptor Immunostaining was observed in myoepithelial, smooth muscle, stromal, and Leydig cells in the testis and, a more intense staining was found in the smooth muscle cells in the region of the epididymis. The distribution of OTR immunostaining and expression on western blotting reinforces the hypothesis proposed by previous studies that oxytocin may stimulate seminiferous tubules and epididymis contractility, and modulate the androgen levels in these tissues, stimulating the conversion of testosterone to dihydrotestosterone (DHT).Results suggest that testicular and epididymal OTR immunolocalization in dogs may be similar to previously studied species. This could indicate that the therapeutic use of oxytocin could be an alternative in infertile dogs, providing new insights to the reproduction and biotechnology in this species.

Keywords: Oxytocin. Oxytocin receptor. Infertility. 


\section{LISTA DE ILUSTRAÇÕES}

Figura 1 - Fotomicrografia do corte transversal de testículo de cão, H/E, $\mathrm{x} 100$. .38

Figura 2 - Fotomicrografia do corte transversal de testículo de cão, $H / E$, x200. .38

Figura 3- Fotomicrografia do corte transversal de epídídimo de cão, H/E, $\mathrm{x} 100$. .39

Figura 4 - Imunolocalização dos receptores de ocitocina no testículo de cão. .40

Figura 5- Imunolocalização dos receptores de ocitocina nas células de Leydig no testículo de cão.

Figura 6- Imunolocalização dos receptores de ocitocina no epidídimo de cão 42

Figura 7- Expressão protéica do receptor de ocitocina em testículos (T) e epidídimos (E) de cães em idade reprodutiva. 44

Quadro 1 - Expressão do mRNA da ocitocina e do receptor de ocitocina no sistema reprodutor masculino em diferentes espécies 
LISTA DE ABREVIATURAS E SIGLAS

$\begin{array}{ll}\text { OT } & \text { Ocitocina } \\ \text { OTR } & \text { Receptor de Ocitocina } \\ \text { AVP } & \text { Vasopressina Arginina } \\ \text { DHT } & \text { Diidrotestosterona } \\ \text { ICSI } & \text { Injeção intracitoplasmática de espermatozóide } \\ \text { SDS } & \text { Dodecil Sulfato de Sódio } \\ \text { Tris-HCI } & \text { Tris-hidroximetil-aminiometano clorídrico } \\ \text { BSA } & \text { Albumina Sérica Bovina } \\ \text { PMSF } & \text { Fenilmetilsulfonilfluoride } \\ \text { PBS } & \text { Tampão fosfato salina } \\ \text { DAB } & \text { Diaminobenzidina }\end{array}$




\section{LISTA DE SÍMBOLOS}

$\begin{array}{ll}\circledR & \text { Marca Registrada } \\ { }^{\circ} \mathrm{C} & \text { Graus Celsius } \\ \% & \text { Porcentagem } \\ \mu & \text { Micra } \\ \mu \mathrm{L} & \text { Microlitro } \\ \mathrm{mM} & \text { Milimolar }\end{array}$




\section{SUMÁRIO}

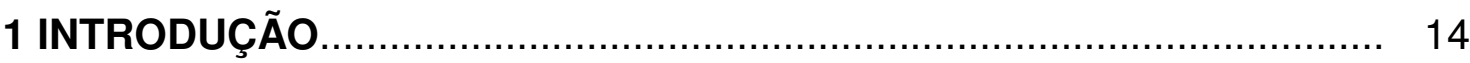

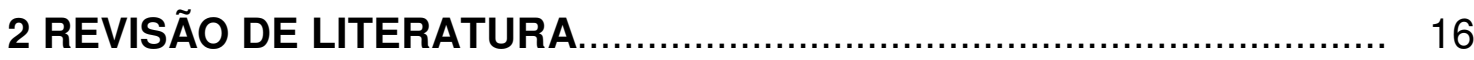

2.1 ESTRUTURA DO GENE DA OCITOCINA E RECEPTOR DE

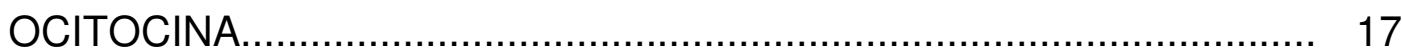

2.2 FARMACOLOGIA DOS RECEPTORES DE OCITOCINA.................... 20

2.3 PAPEL DA OCITOCINA NO COMPORTAMENTO............................. 21

2.4 EFEITOS DA OCITOCINA EM FÊMEAS E MACHOS .......................... 23

2.5 OCITOCINA E ESTEROIDOGÊNESE.............................................., 26

2.6 RECEPTOR DE OCITOCINA E SUA LOCALIZAÇÃO NO TRATO

REPRODUTIVO MASCULINO.................................................... $\quad 27$

2.7 UTILIZAÇÃO TERAPÊUTICA DA OCITOCINA................................... 28

2.8 OCITOCINA E O TRATAMENTO DA INFERTILIDADE HUMANA......... 29

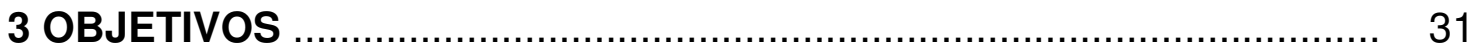

4 MATERIAL E MÉTODOS ............................................................... 32

4.1 REAGENTES, ABREVIATURAS E PROCEDÊNCIA ........................... 32

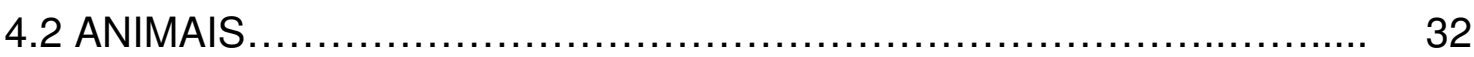

4.2.1 Obtenção e processamento de amostras para imunoistoquímica 33

4.2.2 Obtenção de amostras para a análise da expressão do receptor de Ocitocina......................................................................... 33

4.3 IMUNOLOCALIZAÇÃO DO RECEPTOR DE OCITOCINA.................... 34

4.4 DETERMINAÇÃO PROTÉICA DO RECEPTOR DE OCITOCINA NO EPIDÍDIMO E TESTÍCULO DE CÃES............................................... 35

5 RESULTADOS E DISCUSSÃO.............................................. 37

5.1 MORFOLOGIA DO TESTÍCULO E EPIDÍDIMO................................ 37

5.2 IMUNOISTOQUÍMICA.................................................... 39

5.3 WESTERN BLOTTING ...................................................... 43

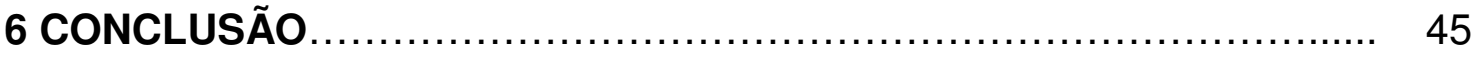

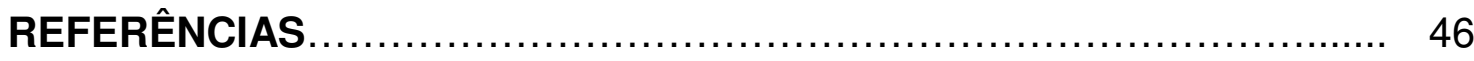




\section{INTRODUÇÃO}

A ocitocina (OT) é um hormônio peptideo liberado pela neurohipófise relacionada a uma ampla variedade de efeitos fisiológicos centrais e periféricos (SHEPARD et al., 2009; FELDMAN; GORDON; ZAGOORY-SHARON, 2010; VIERO et al., 2010; GORDON et al., 2011; EBSTEIN et al., 2012; FELDMAN, 2012; LOPATINA et al., 2012; CARSON et al., 2013 ${ }^{1}$ ), influenciando em diversos níveis na reprodução de todos os vertebrados (ANOUAR et al., 1996; OSTROWSKI, 1998; INABA et al., 1999; GIMPL; FAHRENHOLZ, 2001; FILIPPI et al., 2002; THACKARE; NICHOLSON; WHITTINGTON, 2006; VIERO et al., 2010; DEBLON et al., 2011; GARRISON et al., 2012; MACDONALD, 2012). Este hormônio exerce um papel fundamental na contração do miométrio no momento do parto e na contração das células mioepiteliais da glândula mamária permitindo a ejeção do leite e lactação, apresentando receptores que circundam os alvéolos e ductos mamários (ANOUAR et al., 1996; FUCHS et al., 1996; REZAPOUR; BACKSTROM; ULMSTEN, 1996; ZINGG, 1996; EINSPANIER; IVELL, 1997; KIMURA et al., 1998; INABA et al., 1999; BAE; WATSON, 2003; REVERSI et al., 2005; THACKARE; NICHOLSON; WHITTINGTON, 2006; PRETZER, 2008; LEE et al., 2009; GORDON et al., 2010; LUI et al., 2010; DEBLON et al., 2011; MAGON; KALRA, 2011; CARSON et al., 2013²; KOEHBACH et al., 2013). Outras funções da OT incluem os efeitos no sistema cardiovascular (HATAMI; VALOJERDI; MOWLA, 2007; AHMED; ELOSAILY, 2011; LOPATINA et al., 2012), a regulação da proliferação celular em diferentes tecidos (PETERSSON et al., 2002; REVERSI; CASSONI; CHINI, 2005; HATAMI; VALOJERDI; MOWLA, 2007; SENDEMIR et al., 2008; ZHONG et al., 2010; VRACHNIS et al., 2011), e os efeitos no sistema nervoso central relacionados ao aprendizado, memorização, estresse, desordens neuropsiquiátricas, tendo um papel chave no comportamento social e relacionamento entre os mamíferos (OSTROWSKI, 1998; UVNAS-MOBERG et al., 2001; PRETZER, 2008; SHEPARD et al., 2009; YOUNG, 2009; GORDON et al., 2010; BOWEN et al., 2011; CHEN et al.,

${ }^{1,2}$ CARSON, D. S.; GUASTELLA, A. J.; TAYLOR, E. R.; MCGREGOR, I. S. A brief history of oxytocin and its role in modulating psychostimulant effects. Journal

Psychopharmacology, 2013. 
2011; GORDON et al., 2011; MAGON; KALRA, 2011; TOPS et al., 2011; EBSTEIN et al., 2012; FELDMAN, 2012; LOPATINA et al., 2012; MACDONALD, 2012; POULIN; HOLMAN, 2013³; POURNAJAFI-NAZARLOO et al., 20134).

Embora a OT seja um hormônio muito investigado em fêmeas e mulheres, ainda há uma escassez de estudos sobre este hormônio no sistema reprodutor masculino, principalmente em cães. O envolvimento da OT com a ereção, ejaculação, espermatogênese e maturação do espermatozóide despertou o nosso interesse por este estudo, onde realizamos a imunolocalização dos receptores de ocitocina visando verificar a sua presença ou não no sistema reprodutor de cães machos conforme já descrito para algumas espécies animais (EINSPANIER; IVELL, 1997; FILIPPI et al., 2002; RUSSELL; LENG; DOUGLAS, 2003; HERBERT et al., 2005; GUPTA et al., 2008; LUI et al., 2010; VIERO et al., 2010; LOPATINA et al., 2012; KOEHBACH et al., 2013). Em nosso estudo a imunolocalização dos receptores de ocitocina (OTR) no testículo e epidídimo de cães representou um novo caminho para a reprodução e biotecnologia nesta espécie animal, despertando o interesse pelo possível potencial da utilização terapêutica deste hormônio em machos, fato que já está ocorrendo no tratamento da infertilidade em humanos.

\footnotetext{
${ }^{3}$ POULIN, M. J.; HOLMAN, E. A. Helping hands, healthy body? Oxytocin receptor gene and prosocial behavior interact to buffer the association between stress and physical health. Hormones and Behavior, 2013.

${ }^{4}$ POURNAJAFI-NAZARLOO, H.; KENKEL, W.; MOHSENPOUR, S. R.; SANZENBACHER, L.; SAADAT, H.; PARTOO, L.; YEE, J.; AZIZI, F.; CARTER, C. S. Exposure to chronic isolation modulates receptors MRNAs for oxytocin and vasopressin in the hypothalamus and heart. Peptides, 2013.
} 


\section{REVISÃO DE LITERATURA}

A ocitocina (OT) é composta por nove aminoácidos (Cys- Tyr- Ile- Gln- AsnCys- Pro-Leu-GlyNH $\mathrm{N}_{2}$ ) com uma ponte dissulfito entre as cisteínas 1 e 6 (EINSPANIER; IVELL, 1997; GIMPL; FAHRENHOLZ, 2001; LEE et al., 2009; MAGON; KALRA, 2011; VRACHNIS et al., 2011; EBSTEIN et al., 2012; KOEHBACH et al., 2013). Tem uma estrutura em conformação de anel o que é importante na determinação dos seus efeitos biológicos (YAMAGUCHI; CARDOSO; TORRES, 2007). A sua estrutura é muito similar ao de outro nonapeptídeo denominado vasopressina, diferindo apenas na substituição de dois aminoácidos. É provável que a similaridade justifique as propriedades vasoativas e antidiuréticas da OT quando utilizada em altas doses (GIMPL; FAHRENHOLZ, 2001; LEE et al., 2009). A diferença na posição de seus aminoácidos possibilita a especificidade da interação de cada um dos receptores (ocitocina ou vasopressina) (GIMPL; FAHRENHOLZ, 2001). Há diferenças no efeito fisiológico entre os dois hormônios mediados pela ativação de proteínas $G$ específicas da membrana acopladas a cada um dos receptores (OSTROWSKI, 1998; LEMAIRE et al., 2002; ZHONG et al., 2010). Ainda não foi possível identificar o receptor ou os resíduos de ligação que possam explicar a seletividade dos receptores de ocitocina ( $\mathrm{KOEHBACH}$ et al., 2013). Algumas espécies de vertebrados possuem um peptídeo similar a ocitocina e vasopressina, denominados de isotocina e vasotocina (GIMPL; FAHRENHOLZ, 2001). Desta maneira, duas linhagens moleculares evolutivas foram propostas: a linhagem da OT isotocina-mesotocina associada a funções reprodutivas, e a vasotocinavasopressina envolvida com a homeostase hídrica (GIMPL; FAHRENHOLZ, 2001; LEE et al., 2009).

A OT é primariamente sintetizada pelos neurônios magnocelulares dos núcleos paraventricular e supraóptico do hipotálamo (EINSPANIER; IVELL, 1997; FILIPPI et al., 2002; REVERSI; CASSONI; CHINI, 2005; YAMAGUCHI; CARDOSO; TORRES, 2007; LEE et al., 2009; SHEPARD et al., 2009; FELDMAN; GORDON; ZAGOORY-SHARON, 2010; GORDON et al., 2011; VRACHNIS et al., 2011; FELDMAN, 2012) sendo liberada em um padrão pulsátil no cérebro e em todo o organismo incluindo coração, timo, trato gastrointestinal, útero, placenta, âmnion, 
corpo lúteo e testículo (ZINGG, 1996; YAMAGUCHI; CARDOSO; TORRES, 2007; GORDON et al., 2011; VRACHNIS et al., 2011; FELDMAN, 2012).

A expressão dos OTR é sensível a variações ambientais externas assim como a homeostase corpórea (GORDON et al., 2011). Tanto a OT quanto o OTR foram amplamente estudadas em fêmeas, demonstrando ter participação na contração da musculatura lisa uterina durante o parto e no comportamento materno. Sua ação é observada no comportamento social dos adultos, com um papel na regulação sexual em machos e fêmeas (LEE et al., 2009; SHEPARD et al., 2009; FELDMAN; GORDON; ZAGOORY-SHARON, 2010; GORDON et al., 2011). Em machos de roedores foi observada a sua relação com o funcionamento erétil, cópula e ejaculação. A OT e a vasopressina podem demonstrar ações autócrinas e parácrinas na progressão do tumor em alguns tipos de câncer (ZHONG et al., 2010).

\subsection{ESTRUTURA DO GENE DA OCITOCINA E RECEPTOR DE OCITOCINA}

Em todas as espécies animais os genes da ocitocina e vasopressina estão no mesmo locus cromossômico, porém são transcritos em direções opostas. A distância intergênica entre os genes alcançam 3 a $12 \mathrm{~kb}$ em camundongo, humano e rato (GIMPL; FAHRENHOLZ, 2001; LEE et al., 2009). O RNAm da ocitocina no rato demonstra um aumento no comprimento da cadeia poli $(A)$ em resposta a ativação do sistema hipotálamo-neurohipófise durante a gestação, lactação e desidratação. $O$ útero do rato exibe um aumento na expressão do gene de ocitocina após o parto. $O$ principal sítio para expressão da ocitocina foi o epitélio endometrial onde observa-se um aumento dos OTR e um aumento no RNAm da ocitocina muito próximo do trabalho de parto. O gene da ocitocina em bovino pode ser expresso em tecidos específicos (gônadas), porém não são responsivos ao estradiol. A regulação do gene da ocitocina "in vivo" parece regular potencialidades múltiplas (GIMPL; FAHRENHOLZ, 2001).

O gene do OTR codifica 389 aminoácidos e está presente numa cópia simples do genoma humano no locus 3p25 (EBSTEIN et al., 2012; CARSON et al., 
$2013^{5}$ ). A sequência do receptor de ocitocina (OTR) foi identificada em humanos, porco, rato, ovelha, bovino, camundongo e macaco rhesus. O RNAm do OTR humano pode ser de dois tamanhos: 3,6 kb na mama e 4,4 kb no ovário, endométrio e miométrio (GIMPL; FAHRENHOLZ, 2001). A expressão dos OTR é observada em diversas regiões periféricas como útero, glândula mammária, ovário, rim, coração, osso e células endotelais, assim como amplamente distribuído no sistema nervoso central (CARSON et al., $2013^{6}$ ).

O OTR pertence ao tipo rodopsina classe I acoplado ao receptor da família da proteína G (GPCR) que se liga a fosfolipase C (ZINGG, 1996; GIMPL; FAHRENHOLZ, 2001; HAWTIN; HOWARD; WHEATLEY, 2001; REVERSI; CASSONI; CHINI, 2005; LEE et al., 2009; VRACHNIS et al., 2011; BUSNELLI et al., 2012). As sete alfa hélices transmembrana são mais altamente conservadas entre os membros da família GPCR. Os resíduos conservados entre os GPCRs podem envolver um mecanismo comum de ativação e transdução do sinal pela proteína $G$ (GIMPL; FAHRENHOLZ, 2001; LUI et al., 2010). O OTR possui dois sítios potenciais de $\mathrm{N}$-glicosilação no seu domínio $\mathrm{NH}_{2}$ terminal extracelular em camundongo e rato, ou três sítos em humano, porco, ovino, macaco rhesus e bovino (GIMPL; FAHRENHOLZ, 2001). A ligação da OT na superfície transmembrana da célula leva a ativação do OTR e consequente ativação de sinais intracelulares determinando os efeitos (VRACHNIS et al., 2011). O OTR é uma GRCRs na forma de monômero e oligômero que podem ter funções críticas na comunicação intercelular, não havendo ainda evidências conclusivas que provem os aspectos funcionais destas duas formas (LUI et al., 2010).

Há uma expressão diferenciada do gene do OTR nos diversos tecidos e entre as espécies, assim como variações na sua distribuição. Foi sugerida a presença de subtipos de OTR no útero do rato, rim, cérebro explicando os diferenciados perfis farmacológicos ou de amostras imunoreativas, porém estudos indicaram que há somente um tipo de receptor para a ocitocina (OTR) embora existam 3 tipos de receptores para a vasopressina (V1a, V1b, V2) (FUCHS et al., 1996; ZINGG, 1996; EBSTEIN et al., 2012; KOEHBACH et al., 2013). A alta homologia entre os tipos de

${ }^{5,6}$ CARSON, D. S.; GUASTELLA, A. J.; TAYLOR, E. R.; MCGREGOR, I. S. A brief history of oxytocin and its role in modulating psychostimulant effects. Journal

Psychopharmacology, 2013. 
receptores da vasopressina e ocitocina é encontrada nos contornos extracelulares das hélices transmembrana, porém os grupamentos $\mathrm{NH}_{2}$ terminal e $\mathrm{COOH}$ terminal tem baixa similaridade assim como os contornos intracelulares (GIMPL; FAHRENHOLZ, 2001; HAWTIN; HOWARD; WHEATLEY, 2001).

A OT se liga ao receptor OTR e parece modular a atividade mitótica em diversos tecidos incluindo os osteoblastos (osso), mama, ovário e pequenas células do tumor de pulmão Os seus efeitos na proliferação celular ocorrem em tecidos específicos. (THACKARE; NICHOLSON; WHITTINGTON, 2006; VIERO et al., 2010). O OTR pode estar acoplado a um complexo de proteína Gq ou Gi descritos em diversos tipos celulares. Nos diferentes tipos celulares os múltiplos sinais ativados pelos receptores podem agir sinergicamente ou possuirem efeitos opostos em um mesmo tipo celular. Devido a heterogeneidade da ativação do receptor e os ligantes seletivos podem ser identificadas diferentes funções fisiológicas, assim como ações terapêuticas distintas. Em tumores os OTR/Gi podem determinar sinais para inibição do crescimento celular e parada da migração celular, permitindo o uso da OTR/Gi para a indução da regressão do câncer e prevenção da invasão e metástase de tumores de mama e de próstata (REVERSI; CASSONI; CHINI, 2005; THACKARE; NICHOLSON; WHITTINGTON, 2006; BUSNELLI et al., 2012).

Os OTR em machos e fêmeas são particularmente sensíveis aos esteróides gonadais (GIMPL; FAHRENHOLZ, 2001; LEE et al., 2009). O estrógeno estimula a expressão dos OTR no útero, nas células mioepiteliais da mama durante a gestação e lactação (LEE et al., 2009). Em bovinos o ciclo estral das fêmeas regula o aumento dos OTR no endométrio (FUCHS et al., 1996; GIMPL; FAHRENHOLZ, 2001). Em ratos os sítios de ligação para os OTR e os níveis de RNAm no cérebro aumentam com o tratamento com estrógeno e progesterona e decrescem com a castração (LEE et al., 2009). Atualmente sabe-se que o estrógeno estimula a produção de OTR e a progesterona diminui a sua produção (EBSTEIN et al., 2012). Experimentos sugeriram a presença de um mecanismo alternativo da regulação da OT devido a presença contínua de OTR em determinadas regiões do cérebro após a retirada das gônadas (FUCHS et al., 1996; GIMPL; FAHRENHOLZ, 2001).

O OTR possui uma massa molecular de 40-45 kDa podendo ser calculada na base da sequência de aminoácidos ácidos derivadas da sequência de cDNA de algumas espécies. A fotoafinidade de alguns experimentos de marcação utilizando membranas do miométrio obtidos de cobaia na gestação tardia foi de 68 a 80 kDa de 
proteína pela marcação do antagonista da ocitocina. Membranas de glândula mamária de rato e células do âmnion de coelho demonstraram a fotoreatividade em 65 kDa (GIMPL; FAHRENHOLZ, 2001). Na cervix de ovinos foi observada a massa molecular do OTR de $66 \mathrm{KDa}$ (FALCHI; SCARAMUZZI, 2013). É possível que as diferenças de massas moleculares do miométrio, glândula mamária e âmnion para o OTR tenham relação com a diferenciação de glicosilação entre as amostras (GIMPL; FAHRENHOLZ, 2001).

\subsection{FARMACOLOGIA DOS RECEPTORES DE OCITOCINA}

A ocitocina está envolvida em diversos mecanimos centrais determinando alterações comportamentais. O uso de agonistas e antagonistas para efeitos periféricos devem levar em consideração as ações centrais devido a passagem das substâncias pela barreira hematoencefálica (CLARK et al., 2009; LEE et al., 2009; MAGON; KALRA, 2011). Considerando que a ocitocina tem somente um receptor, ao contrário da vasopressina que possui 3 subtipos descritos até o momento, os estudos caminham para a opção de agonistas e antagonistas (ambos peptídeos e moléculas pequenas) que tenham especificidade para os OTR e pouca ou nenhuma atividade nos receptores de vasopressina. Dois dos conhecidos antagonistas são o Atosiban que é clinicamente utilizado para o trabalho de parto prematuro e o OVTA, porém ambos possuem atividade no receptor de vasopressina (LEE et al., 2009; VRACHNIS et al., 2011). A ocitocina sintética (Pitocin) é utilizada para indução do trabalho de parto e para auxílio na produção de leite. Há antagonistas altamente específicos como o SSR126768 e GSK2211149A que podem ser eventualmente encontrados para uso clínico. Os agonistas dos nonapeptídeos estão em desenvolvimento (LEE et al., 2009; VRACHNIS et al., 2011). A meia vida da ocitocina varia de 5 a 7 minutos e a forma ativa da molécula liga-se pouco as proteínas plasmáticas. A depuração da OT é renal e hepática e somente uma pequena fração é liberada pela urina de forma inalterada (YAMAGUCHI; CARDOSO; TORRES, 2007). 


\subsection{PAPEL DA OCITOCINA NO COMPORTAMENTO}

A OT está envolvida com o comportamento sendo importante na regulação da memória social, comportamento afetivo ou agressivo. O comportamento social determina respostas individuais e a formação da memória social dos indivíduos determinando características apropriadas dentro do grupo. Envolvem o comportamento entre indivíduos do mesmo sexo e de sexos diferentes como no comportamento reprodutivo (EINSPANIER; IVELL, 1997), afetivo, materno, agressivo e o competitivo (LEE et al., 2009; SHEPARD et al., 2009; FELDMAN; GORDON; ZAGOORY-SHARON, 2010; BOWEN et al., 2011; CAMPBELL et al., 2011; GORDON et al., 2011; MAGON; KALRA, 2011; EBSTEIN et al., 2012; FELDMAN, 2012; OPHIR et al., 2012).

$O$ reconhecimento social difere entre machos e fêmeas. Nas fêmeas o papel central da ocitocina no comportamento e fisiologia depende muito dos hormônios esteróides (LEE et al., 2009; SHEPARD et al., 2009). A prolactina é liberada na presença da ocitocina associada ao estímulo vagino-cervical (LEE et al., 2009). Os genes promotores da OT no rato e humano contém elementos de resposta para estrogênio e são estimulados pelo estrógeno e hormônios tireoideanos (LEE et al., 2009). Acredita-se que a ação central do estrógeno e andrógeno na regulação do comportamento social seja mediado pela ocitocina e a vasopressina arginina (AVP). Os estudos demonstraram que a AVP influencia o comportamento dos machos e a OT no das fêmeas, pois a ação central da AVP envolve a agressividade, relacionamento e o reconhecimento social entre os machos de muitos mamíferos, embora sua ação periférica tenha envolvimento na regulação da homeostase hídrica (SHEPARD et al., 2009). Estudos com administração de ocitocina demonstraram o aumento na resposta do reconhecimento social entre os machos, interferindo na habilidade do reconhecimento do odor (LEE et al., 2009; SHEPARD et al., 2009; OPHIR et al., 2012). A testosterona parece regular os efeitos da vasopressina e o estrógeno os efeitos da ocitocina no reconhecimento social de fêmeas (LEE et al., 2009; SHEPARD et al., 2009).

O papel da OT no controle da agressividade em machos é ambíguo dependendo da espécie, status sexual e idade. Em alguns casos o efeito na agressividade pode ter relação com o estresse, e pode ser bloqueado com a 
administração concomitante da ocitocina e o seu antagonista (LEE et al., 2009). As fêmeas são mais agressivas durante o período posterior ao parto. A ocitocina parece exercer uma influência na agressividade materna por meio do seu papel na modulação da ansiedade. Em roedores a mãe pode atacar um macho não familiar introduzido após o nascimento da cria. Este tipo de agressão é um comportamento complexo influenciado por diversos fatores ainda estudados (LEE et al., 2009; GORDON et al., 2011).

Em humanos pouco se conhece do papel da ocitocina no comportamento e agressividade, podendo ter relação com a diminuição da ansiedade devido ao reconhecimento e sentimentos de filiação (LEE et al., 2009; SHEPARD et al., 2009; GORDON et al., 2011; FELDMAN, 2012). A OT exerce efeitos no comportamento social, memória, depressão, estresse, sendo considerado um facilitador da interação entre os casais e sentimentos de proximidade (LEE et al., 2009; SHEPARD et al., 2009; FELDMAN; GORDON; ZAGOORY-SHARON, 2010; GORDON et al., 2011; FELDMAN, 2012). Acredita-se que anormalidades na produção da OT (polimorfismos no gene) possam ter relação com 0 autismo, desordem neurofisiológica caracterizada pelo comportamento social anormal, comportamentos repetitivos e estereotipados, retardamento, convulsões e elevada ansiedade. A infusão intravenosa da ocitocina em adultos com autismo tem reduzido significantemente a severidade destes comportamentos repetitivos (auto-injúria, repetição), aumentando a habilidade de compreender e memória de componentes afetivos de palavras faladas (feliz, indiferente, bravo ou triste) (LEE et al., 2009; CAMPBELL et al., 2011; TOPS et al., 2011; EBSTEIN et al., 2012; FELDMAN, 2012). A OT parece estar relacionada a outras desordens psiquiátricas como a esquizofrenia, ansiedade e depressão, porém estudos ainda estão sendo realizados sobre 0 assunto possibilitando aumentar o potencial da utilização dos neuropeptídeos no tratamento das desordens sociais (LEE et al., 2009; TOPS et al., 2011; FELDMAN, 2012). 


\subsection{EFEITOS DA OCITOCINA EM FÊMEAS E MACHOS}

A ocitocina na fêmea é considerada um hormônio miotônico causando a contração da musculatura uterina e das células mioepiteliais da glândula mamária (THACKARE; NICHOLSON; WHITTINGTON, 2006; MAGON; KALRA, 2011).

Nos machos a OT modula a contratilidade do trato reprodutor masculino regulando o transporte e maturação do espermatozóide (EINSPANIER; IVELL, 1997; WHITTINGTON et al., 2001; FILIPPI et al., 2002; THACKARE; NICHOLSON; WHITTINGTON, 2006; GUPTA et al., 2008; MAGON; KALRA, 2011). A OT aumenta a contratilidade da musculatura lisa do testículo, epidídimo e próstata, induz a ereção peniana e ejaculação, modulando o comportamento sexual (EINSPANIER; IVELL, 1997; FRAYNE; NICHOLSON, 1998; WHITTINGTON et al., 2001; FILIPPI et al., 2002; THACKARE; NICHOLSON; WHITTINGTON, 2006; GUPTA et al., 2008; SENDEMIR et al., 2008; MAGON; KALRA, 2011). Este hormônio influencia na contratilidade das células mioepiteliais ao redor dos túbulos seminíferos de ratos (INABA et al., 1999; GUPTA et al., 2008). Tanto "in vitro" como "in vivo" a OT tem sido relacionada ao aumento da contratilidade do epidídimo, ducto deferente e próstata de humanos, coelho, camundongo e rato como também na ejaculação nestas espécies (GUPTA et al., 2008). A presença dos receptores em todo o reprodutor masculino sugere a ação periférica da OT (WHITTINGTON et al., 2001; RUSSELL; LENG; DOUGLAS, 2003). Os receptores estão presentes nas células epiteliais, Sertoli e Leydig (humano, macaco, marmoset e rato), no testículo, estroma da próstata com exceção da musculatura lisa do epidídimo distal e tecido erétil, indicando um papel essencial na esteroidogênese (RUSSELL; LENG; DOUGLAS, 2003).

A influência da OT na ejaculação permite que este hormônio seja considerado o principal facilitador da emissão do sêmen. Estudos demonstraram que os níveis plasmáticos da OT aumentam no momento da ejaculação em carneiro, bovinos, coelhos e no homem. Este aumento pode ser estar relacionado ao aumento do volume de esperma e da concentração no ejaculado em diversas espécies animais (RUSSELL; LENG; DOUGLAS, 2003). A ejaculação é um evento de 2 fases que inclui a emissão e expulsão do sêmen. A primeira fase constitui a contração peristáltica do epidídimo, vesícula seminal, próstata e colo da bexiga propulsionando 
o fluido seminal na uretra posterior. A segunda fase envolve a contração ritmica da musculatura estriada da parte inferior da pelve (RUSSELL; LENG; DOUGLAS, 2003).

A espermatogênese é um processo organizado que ocorre em estágios morfológicos distintos com arranjos lineares no túbulo seminífero. Os espermatozóides não móveis seguem pelo túbulo seminífero em um processo denominado de espermiogênese e no final do estágio VIII são transportados pelo lúmen do túbulo para a rede testis. O transporte é mediado pela contração das células mioepiteliais que circundam os túbulos seminíferos. Dois tipos de contratilidade tubular (tipo A e tipo B) tem sido descritas. O movimento tipo A são de alta frequência como ondas da parede dos túbulos, entretanto os movimentos tipo $B$ incluem grandes contrações, envolvendo secções inteiras do túbulo e estão associadas aos movimentos em massa do conteúdo seminal e transporte do espermatozóide a partir do testículo. Os movimentos tipo B ocorrem com menor frequência quando comparados ao movimento do tipo A (THACKARE; NICHOLSON; WHITTINGTON, 2006). Estudos indicam que ambos os movimentos podem ser melhorados pela adição de pequenas quantidades de ocitocina $(1 \mathrm{ng} / \mathrm{mL})$ (THACKARE; NICHOLSON; WHITTINGTON, 2006). Experimentos "in vitro" demonstraram que ratos machos adultos destituídos de células de Leydig devido a tratamento químicos possuem o retorno de suas atividade normais assim com o de sua morfologia quatro semanas após a administração de OT (THACKARE; NICHOLSON; WHITTINGTON, 2006).

O epidídimo possui múltiplas funções variando da maturação ao armazenamento. A contratilidade do epidídimo é importante para o movimento e maturação do espermatozóide, e esta pode ser modificada por uma variedade de agentes incluindo a OT (EINSPANIER; IVELL, 1997; WHITTINGTON et al., 2001; THACKARE; NICHOLSON; WHITTINGTON, 2006). Em camundongos a ocitocina aumenta a contratilidade da cauda do epidídimo "in vitro" sugerindo um papel de propulsão do esperma da cauda para o canal deferente e ejaculação. A ocitocina "in vivo" produz um aumento progressivo na amplitude e frequência da contração bem como o tônus do túbulo epididimário. Ao estimular a contratilidade há diminuição do tempo pós cópula durante o qual as reservas de esperma do epidídimo estão reduzidas. Os estudos "in vitro" demonstraram que a OT pode regular a contratilidade do epidídimo e o transporte do esperma. A ocitocina (10 a $100 \mu \mathrm{g}$ ) 
aumenta significantemente tanto a eliminação de fluido como na quantidade de espermatozóides do fluido luminal da cauda do epidídimo nos 10 minutos do tratamento, com efeito dose dependente (WHITTINGTON et al., 2001; THACKARE; NICHOLSON; WHITTINGTON, 2006). Os espermatozóides não são capazes de exibir sua motilidade no trato reprodutor masculino e por isso necessitam ser transportados do testículo, sendo maturados e estocados no epidídimo. O estoque pode ocorrer por um período de tempo variável entre as espécies até sua liberação pelo ducto deferente na ejaculação. A liberação do espermatozóide do epidídimo é o primeiro passo no processo de ejaculação ocorrendo em conjunto com a atividade de contrátil das células musculares lisas distribuídas de maneira diferenciada nas regiões de cabeça, corpo e cauda do epidídimo (FILIPPI et al., 2002; THACKARE; NICHOLSON; WHITTINGTON, 2006). Na cabeça do epidídimo as células contráteis formam uma camada solta ao redor dos túbulos, na cauda estas células são substituídas por uma espessa camada de células musculares lisas organizadas em três camadas distintas. A atividade contrátil do epidídimo é regulada pela via noradrenérgica e por hormônios como a OT envolvidos na regulação desta motilidade e da liberação do sêmen (FILIPPI et al., 2002).

Diferentes mecanismos neurais e/ou endócrinos estão envolvidos na regulação da ereção peniana (THACKARE; NICHOLSON; WHITTINGTON, 2006), sendo a OT considerada um dos mais potentes agentes indutores da ereção peniana em machos agindo em conjunto com a testosterona. Estudos indicaram que animais castrados somente puderam ter a ereção restabelecida após a administração de ocitocina em conjunto com a testosterona. No rato o óxido nítrico tem sido considerado a chave mediadora desta ação (THACKARE; NICHOLSON; WHITTINGTON, 2006). Acredita-se que os altos níveis de ocitocina contribuam com a sensação de saciedade sexual (LEE et al., 2009).

Há interação da ocitocina com o sistema dopamina e serotonina. A injeção da dopamina induz a ereção peniana e a depleção de serotonina é um fator subjacente na ejaculação prematura em ratos e humanos (LEE et al., 2009). Os agonistas do receptor da serotonina mostraram produzir um aumento de ocitocina, e a utilização de inibidores da recaptação da serotonina usados no tratamento da depressão tem mostrado inibir o orgasmo e induzir um decréscimo transitório da libido tempo e dose dependente (THACKARE; NICHOLSON; WHITTINGTON, 2006). 
Na próstata a OT tem um papel fisiológico no aumento da atividade contrátil da musculatura lisa e está envolvido com a manutenção do tônus desta glândula, contração e ejaculação e transporte do sêmen. Além disso relaciona-se ao aumento do crescimento da próstata em rato, cão e humano (HERBERT et al., 2005). A OT está presente na próstata em concentrações mais altas que a plasmática, podendo aumentar o tônus muscular e estar relacionada com a liberação da secreção prostática na ejaculação em cobaias, porco, rato, cão e humano (EINSPANIER; IVELL, 1997; FRAYNE; NICHOLSON, 1998; GIMPL; FAHRENHOLZ, 2001). No testículo de roedores a OT estimula a conversão da testosterona em diidrotestosterona (SENDEMIR et al., 2008). No homem a ocitocina pode ser encontrada no corpo cavernoso e epidídimo podendo afetar a contratilidade e ejaculação (EINSPANIER; IVELL, 1997; LEE et al., 2009). A intensidade do orgasmo em homens e mulheres está relacionada com os níveis de ocitocina plasmática, pois os níveis plasmáticos de ocitocina aumentam durante a excitação sexual e orgasmo (THACKARE; NICHOLSON; WHITTINGTON, 2006; LEE et al., 2009).

\subsection{OCITOCINA E ESTEROIDOGÊNESE}

A síntese de ocitocina pelas células de Leydig juntamente com a presença de OTR sugerem que a OT exerça um papel na modulação da esteroidogênese testicular (WHITTINGTON et al., 2001; THACKARE; NICHOLSON; WHITTINGTON, 2006). Apesar de estudos controversos sugere-se que a vasopressina arginina e hormônios neurohipofisários influenciem na inibição direta da biosíntese do andrógeno testicular "in vitro". Estudos "in vivo" com a administração intratesticular de OT no rato adulto demonstraram significante redução da testosterona testicular e plasmática num período de 4 semanas com um concomitante aumento dos níveis de diidrotestosterona (DHT), sem que houvesse alterações na espermatogênese ou na contagem espermática. Estes dados sugerem que a OT estimula a conversão da testosterona em DHT explicando a não alteração na espermatogênese e contagem espermática. A administração aguda de OT estimula a produção de testosterona principalmente em animais jovens, sendo que a prolongada exposição ao OT resulta em declínio na concentração de testosterona e aumento na produção de DHT. O 
aumento na produção de andrógeno após a aplicação de OT se deve a ação que exerce na hipófise (THACKARE; NICHOLSON; WHITTINGTON, 2006).

A OT pode regular a esteroidogênese local no testículo e epidídimo devido a estimulação da conversão da testosterona para diidrotestosterona (DHT). Por meio deste processo provavelmente a OT esteja relacionada ao desenvolvimento da hiperplasia benigna de próstata (WHITTINGTON et al., 2001; HERBERT et al., 2005; THACKARE; NICHOLSON; WHITTINGTON, 2006). Na próstata a OT parece estimular a conversão da testosterona em DHT pela estimulação da atividade da enzima $5 \alpha$ redutase. As alterações da atividade desta enzima provavelmente refletem a direção da sua ação e a estimulação de sua síntese. Na próstata do cão e humano as concentrações são positivamente correlacionadas com os andrógenos indicando diferenças entre as espécies nos mecanismos de feedback locais para regulação da OT e sua interação com os andrógenos (THACKARE; NICHOLSON; WHITTINGTON, 2006).

\subsection{RECEPTOR DE OCITOCINA E SUA LOCALIZAÇÃO NO TRATO REPRODUTIVO MASCULINO}

Um pré requisito para a ação da ocitocina em machos é a presença de receptores com localizações específicas em cada espécie (tabela 01) (FRAYNE; NICHOLSON, 1998). A ocitocina possui efeitos heterogêneos que possivelmente estejam relacionados a diferentes vias de sinalização e a localização diferencial de seus receptores (OTR), já que estudos revelaram a presença de um único receptor (há somente um gene do OTR expressado nos diferentes tecidos) (SENDEMIR et al., 2008; LEE et al., 2009). 
Quadro 1- Expressão do mRNA da ocitocina e do receptor de ocitocina no sistema reprodutor masculino em diferentes espécies

\begin{tabular}{|c|c|c|c|}
\hline Tecido & Espécie & Síntese de Ocitocina & Receptor de Ocitocina \\
\hline \multicolumn{4}{|l|}{ Testículo } \\
\hline & Humano & Detectado & Detectado \\
\hline & Marmoset & Detectado & Detectado \\
\hline & Macaco & --- & Detectado \\
\hline & Rato & Detectado & Detectado \\
\hline & Porco & --- & Detectado \\
\hline & Carneiro & Detectado & Detectado \\
\hline & Boi & Detectado & $-\ldots$ \\
\hline & Wallaby & --- & Não detectado \\
\hline \multicolumn{4}{|l|}{ Epidídimo } \\
\hline & Humano & Detectado & Detectado \\
\hline & Sagui & Fracamente detectado & Fracamente detectado \\
\hline & Macaco & --- & Detectado \\
\hline & Rato & Detectado & --- \\
\hline & Porco & --- & Detectado \\
\hline & Carneiro & Detectado & Detectado \\
\hline & Boi & --- & ---- \\
\hline & Wallaby & --- & Detectado \\
\hline \multicolumn{4}{|l|}{ Próstata } \\
\hline & Humano & Detectado & Detectado \\
\hline & Sagui & Não detectado & Detectado \\
\hline & Macaco & --- & Detectado \\
\hline & Rato & --- & Detectado \\
\hline & Porco & --- & --- \\
\hline & Carneiro & --- & --- \\
\hline & Boi & --- & --- \\
\hline & Wallaby & --- & Detectado \\
\hline \multicolumn{4}{|l|}{ Pênis } \\
\hline & Humano & --- & Detectado \\
\hline & Sagui & --- & --. \\
\hline & Macaco & --- & --- \\
\hline & Rato & --- & Detectado \\
\hline & Porco & --- & --- \\
\hline & Carneiro & --- & --- \\
\hline & Boi & --- & ---- \\
\hline & Coelho & --- & Detectado \\
\hline
\end{tabular}

Fonte: (TACKARE et al., 2006)

\subsection{UTILIZAÇÃO TERAPÊUTICA DA OCITOCINA}

$\mathrm{Na}$ mulher o uso primário da ocitocina relaciona-se ao trabalho de parto e ao aumento das contrações uterinas. A ocitocina pode ser usada para facilitar a 
amamentação em casos específicos, aumentando em conjunto a lubrificação vaginal e a excitação. Estudos indicam a possibilidade de ação da OT em processos inflamatórios permitindo a hipótese de que a OT atenua processos próinflamatórios como a aterosclerose em modelos de rato (AHMED; ELOSAILY, 2011). Atualmente sugere-se que a OT pode exercer uma série de efeitos metabólicos benéficos representando uma alternativa terapêutica para o tratamento da obesidade humana e o diabetes tipo 2 (DEBLON et al., 2011).

A aplicação exógena da ocitocina melhora o comportamento materno e facilita o relacionamento social, exercendo um efeito ansiolítico. Na medicina veterinária a ocitocina sintética está disponível podendo ser administrada pelas vias intravenosa, subcutânea e intramuscular. Não é recomendada a administração via oral da OT, pois por ser um hormônio peptídeo pode ser destruído no estômago (PRETZER, 2008). A OT não se liga a proteínas plasmáticas e é metabolizada nos rins e fígado, possuindo uma meia vida de 5 minutos e não apresentando efeitos tóxicos, sendo amplamente utilizada no tratamento da distocia em cães (KLARENBEEK et al., 2007). Prefere-se a administração em pequenas doses (1-3 U/ subcutânea ou intramuscular), pois doses elevadas podem provocar ruptura uterina, descolamento da placenta, morte fetal, vasodilatação e hipertensão materna (PRETZER, 2008). O profissional deve ter cautela na sua utilização para que não sejam desencadeados problemas posteriores a sua administração (CLARK et al., 2009).

\subsection{OCITOCINA E O TRATAMENTO DA INFERTILIDADE MASCULINA}

Em humanos a injeção intracitoplasmática (ICSI) é o único tratamento disponível para a infertilidade masculina devido a severa e irreversível oligospermia ou azospermia. A OT "in vitro" melhora a espermiogênese e o transporte do esperma em alguns modelos animais podendo melhorar a quantidade de esperma presente no ejaculado. Os efeitos da ocitocina podem sugerir um potencial avanço nos programas de congelamento de sêmen. Os estudos em animais sugerem que o homem com oligospermia podem ser beneficiados com a administração de ocitocina (FILIPPI et al., 2002; THACKARE; NICHOLSON; WHITTINGTON, 2006). Considerando as funções da ocitocina qu envolvem o aumento da espermiogênese 
e do transporte do esperma, a indução da ereção peniana, a regulação da proliferação celular, a menor imunoreatividade com a progressão do tumor prostático, as possíveis aplicações clínicas da OT incluem a oligospermia, tratamento da impotência e desordens da ejaculação, tratamento da hiperplasia prostática benigna, marcador de tumor de próstata (FILIPPI et al., 2002; THACKARE; NICHOLSON; WHITTINGTON, 2006). No homem normalmente a concentração basal de ocitocina é muito baixa, tendo um breve aumento com o estímulo da contração do sistema reprodutor liberando o sêmen no orgasmo. Há evidências que a administração exógena em homens inférteis melhora a qualidade do sêmen ejaculado (LUI et al., 2010). A OT tem ação local no sistema reprodutor masculino sendo sintetizada localmente no testículo, epidídimo, próstata, pênis, tendo a expressão dos OTR pelo trato reprodutivo (LUI et al., 2010). Os estudos indicam que há diferença significativa na concentração basal da ocitocina e a expressão dos receptores entre homens inférteis. O aumento da concentração basal da ocitocina no soro leva a um decréscimo na expressão dos oligomeros dos OTR e aumento dos monômeros (LUI et al., 2010). 


\section{OBJETIVOS}

Detectar a presença e a distribuição do receptor de ocitocina (OTR) no testículo e epidídimo de cães pela análise imunoistoquímica e western blotting correlacionando a distribuição com o possível papel exercido pela OT em cada um dos tecidos. 


\section{MATERIAL E MÉTODOS}

\subsection{REAGENTES, ABREVIATURAS E PROCEDÊNCIA}

Amersham Biosciences (Uppsala, Suécia): azul de bromofenol, Tween-20; Bio-Rad (CA, USA): padrão de peso molecular para proteínas Kaleidoscope; Calbiochem (EMD Chemicals, Inc., CA, USA): NP-40; Invitrogen Life Technologies (Carlsbad, CA, EUA): dodecil sulfato de sódio (SDS), Acrilamida; Leica: Novolink Polymer Detection System; Merck KGaA (Darmstadt, Germany): tris-hidroximetil-aminometano clorídrico (Tris-HCl), cloreto de sódio, hidróxido de sódio, metanol; Sigma-Aldrich Co (St Louis, MO, EUA): anticorpo policlonal antireceptor de ocitocina desenvolvido em coelho; ExtrAvidin®-peroxidase, albumina sérica bovina (BSA), Triton X-100, anti- $\beta$-actina feito em camundongo, anticorpo secundário anti-lgG de camundongo feito em cabra, fenilmetilsulfonilfluoride (PMSF), ortovanadato de sódio, benzamidina, leupeptina, aprotinina, ácido deoxicolato de sódio, pirofosfato de sódio tetrabásico, fluoreto de sódio, 2-mercaptoetanol. Vector Laboratories, Inc. (Burlingame, CA, USA): anticorpo secundário biotinilado anti $\lg G(H+L)$ de coelho feito em cabra.

\subsection{ANIMAIS}

Todos os procedimentos experimentais mencionados foram realizados de acordo com os princípios éticos adotados pelo Colégio Brasileiro de Experimentação Animal, submetidos e aprovados pela Comissão de Ética em Experimentação Animal da Faculdade de Medicina Veterinária e Zootecnia da Universidade de São Paulo no 1912/2010. As amostras de testículo e epidídimo foram coletadas de cães clinicamente normais em idade reprodutiva entre 1 a 6 anos, obtidas em cirurgia eletiva de orquiectomia em clínicas veterinárias. Foram utilizados 5 animais para análise da imunoistoquímica e 4 animais para a análise pelo western blotting. 


\subsubsection{Obtenção e processamento de amostras para imunoistoquímica}

As amostras para a imunoistoquímica foram identificadas e imersas em formaldeído $10 \%$ devidamente refrigeradas, e processadas no laboratório de Endocrinologia de Peixes no departamento de Biologia Celular e do Desenvolvimento do Instituto de Ciências Biomédicas da Universidade de São Paulo sob a orientação a Prof ${ }^{a}$ Dr $^{\text {a }}$ Maria Inês Borella. Após um período de 12 horas de fixação os testículos e epidídimos foram recortados em fragmentos menores que foram identificados e foram imersos novamente no formaldeído a 10\%. Para o controle negativo foram utilizadas amostras de pele de cão e como controle positivo amostras de útero de cão recortadas em fragmentos de $0,5 \mathrm{~cm}^{3}$. Após 24 horas de fixação em formaldeído a $10 \%$ as amostras foram lavadas em tampão fosfato salina (PBS) e processadas rotineiramente para inclusão em parafina (Histosec® - Merck, Darmstadt, Alemanha). Este processamento incluiu os processos de desidratação (etanol 50\%, etanol 70\%, etanol, $85 \%$, etanol 95\%, etanol 100\%), diafanização (xilol), xilol/parafina (1:1), xilol/parafina (1:2), parafina pura, e inclusão em parafina dos fragmentos coletados e fixados. Após a inclusão foram obtidos cortes de $4 \mu \mathrm{m}$ de espessura no micrótomo e a colocação em lâminas ionizadas para os procedimentos de coloração em hematoxilina e eosina e imunoistoquímica.

\subsubsection{Obtenção de amostras para a análise da expressão do receptor de Ocitocina}

Para a análise da expressão protéica do receptor de ocitocina utilizou-se amostras de testículo e epidídimo de cães coletadas das cirurgias eletivas de orquiectomia totalizando 4 animais. Para a análise da presença do receptor de ocitocina em testículos e epidídimos caninos, as amostras foram coletadas em fenilmetilsufonil fluorido (PMSF) 0,01M diluído em TBS 0,02M e conservados em tampão RIPA ( $\mathrm{NaCl} 150$ mM, NP-40 1,0\%, ácido deoxicolato de sódio 0,5\% em Tris$\mathrm{HCl}, \mathrm{pH} 7,5$ ) contendo um coquetel de proteases (PMSF 1,0 mM, ortovanadato de sódio 1,0 mM, benzamidina 0,45 mg/mL, leupeptina 1,0 mM e aprotinina 1,0 mM) a - 
$80{ }^{\circ} \mathrm{C}$ até o momento de uso. A reação de western blotting foi realizada no laboratório de citofisiologia do trofoblasto do Departamento de Biologia Celular e do Desenvolvimento do Instituto de Ciências Biomédicas da Universidade de São Paulo sob a supervisão da Prof $^{-a}$ Dr $^{-a}$ Estela Maris Forell Bevilacqua.

\subsection{IMUNOLOCALIZAÇÃO DO RECEPTOR DE OCITOCINA}

Os cortes de $4 \mu \mathrm{m}$ de espessura do material incluído em Histosec $®$ e colocados em lâminas ionizadas foram desparafinados em banhos de xilol a 60ำ por 30 minutos, a temperatura ambiente por 20 minutos e então reidratados em uma série de concentrações decrescentes de etanol. Para remoção do pigmento formólico foi utilizada uma solução de hidróxido de amônio 10\% em etanol 95\% por 10 minutos, seguidas de lavagem em água corrente.

A recuperação antigênica foi realizada com ácido cítrico $10 \mathrm{mM}, \mathrm{pH} 6,0$, em microondas $(700 \mathrm{~W})$ por 1 minuto e em seguida as amostras foram lavadas em água corrente. Seguiu-se a utilização do kit Novolink Polymer Detection System $®$ (Leica) para incubação com a anticorpo secundário e terciário e o complexo de amplificação. Após a recuperação antigênica as lâminas foram lavadas tampão fosfato salina (PBS) $\mathrm{pH} 7,4$, seguiu-se a neutralização da peroxidase endógena com a solução Peroxidase Block por 5 minutos. As lâminas foram lavadas com tampão PBS pH 7,4 seguindo-se da incubação com a solução protein block por 5 minutos.

A seguir as lâminas foram novamente lavadas em tampão PBS pH 7,4 e incubadas com anticorpo primário anti-oxytocin receptor produzido em coelho na concentração de 1:200 (Sigma®, O4389) em PBS pH 7,4. As lâminas foram colocadas em câmara úmida, "overnight" a $4^{\circ} \mathrm{C}$. Como controle positivo da reação foram utilizadas amostras de útero de cão, e como controle negativo amostras de pele de cão. Também foram utilizadas amostras de testículo suprimindo o anticorpo primário como controle negativo.

Após este período as lâminas serão lavadas em tampão PBS, pH 7,4, e incubadas com a solução post primary block durante 30 minutos. Seguiu-se a lavagem com tampão PBS pH 7,4 e a incubação no polímero por 30 minutos. Em leve agitação realizou-se a lavagem das lâminas e a utilização do cromógeno 3,3 
diaminobenzidina (DAB) por até 5 minutos. As lâminas foram enxaguadas em água, contrastadas com hematoxilina, enxaguadas novamente, desidratadas, diafanizadas e montadas com goma de Damar para análise na microscópio de luz Nikon® e documentação.

\subsection{DETERMINAÇÃO PROTÉICA DO RECEPTOR DE OCITOCINA NO EPIDÍDIMO E TESTÍCULO DE CÃES}

A determinação protéica do receptor de ocitocina em testículos e epidídimos caninos foi realizada por Western Blotting utilizando-se anticorpo primário antioxytocin receptor produzido em coelho (Sigma Chemical Co.), seguido da incubação com o anticorpo secundário biotinilado anti lgG de coelho produzido em cabra (Vector Laboratories, Inc) e posteriormente, da incubação com avidina conjugada com peroxidase (Sigma-Aldrich Co.)

Os fragmentos foram coletados em fenilmetilsufonil fluoridrico (PMSF) $0,01 \mathrm{M}$ diluído em TBS 0,02M e conservados em tampão RIPA ( $\mathrm{NaCl}$ 150mM, NP-40 1,0\%, ácido deoxicolato de sódio $0,5 \%$ em Tris- $\mathrm{HCl}, \mathrm{pH} 7,5)$ contendo um coquetel de proteases (PMSF 1,0mM, Ortovanadato de sódio - $\mathrm{NA}_{3} \mathrm{VO}_{4} 1,0 \mathrm{mM}$ - benzamidina $0,45 \mathrm{mg} / \mathrm{mL}$, leupeptina $1,0 \mathrm{mM}$ e aprotinina $1,0 \mathrm{mM}$ ) a $-80{ }^{\circ} \mathrm{C}$. As amostras foram processadas utilizando-se 0 homogeinizador de tecidos Precellys $\AA_{2} 4$ (Bertin Technologies, Montigny-le-Bretonneux, França) e centrifugação a 12.000rpm (10 minutos, $4{ }^{\circ} \mathrm{C}$ ). $\mathrm{O}$ sobrenadante foi coletado e $1 \mu \mathrm{L}$ da amostra utilizado para quantificação da proteína total em um espectrofotômetro (ELX 800, Bio-Tek Instruments, Inc., VT, USA) com filtro de $595 \mathrm{\eta m}$, com reagente Bradford (BRADFORD, 1976).

Após a determinação da concentração protéica, $30 \mu \mathrm{g}$ de proteína de cada amostra foram diluídas em tampão $85 \mathrm{mM}$ Tris contendo 2,5\% de 2-mercaptoetanol, $17 \%$ glicerol, $0,1 \%$ SDS e $0,4 \%$ azul de bromofenol diluídos em água milliQ, onde permaneceram por $5 \mathrm{~min}$ a $100{ }^{\circ} \mathrm{C}$ em placa de banho seco (DB-2A, TECHNE, Bibby Scientific Limited, Staffordshire, UK). Em seguida, as amostras foram distribuídas nos poços do gel e submetidas à separação eletroforética em mini gel de poliacrilamida $12,5 \%$ com SDS-PAGE, a uma voltagem de $100 \mathrm{~V}$ e corrente de 25 
mA durante cerca de 2 horas em um aparelho Mighty Slim SX 250 Power supply (Hoefer, San Francisco, CA, USA). Como padrão de peso molecular, utilizou-se o padrão comercial Kaleidoscope (Bio-Rad, CA, USA).

Posteriormente, as proteínas separadas no gel foram transferidas para membranas de nitrocelulose (Immobilon, 0,45 $\mu \mathrm{m}$, Millipore, Billerica, MA) a uma voltagem variável, e corrente constante de $200 \mathrm{~mA}$ por duas horas à $4^{\circ} \mathrm{C}$, em um equipamento de transferência úmida (Bio-Rad, CA, USA). As membranas de nitrocelulose foram em seguida incubadas com 3\% de BSA em TBS contendo $0,1 \%$ Tween 20 (TTBS), pH 7,4, durante 1 h, para bloqueio de sítios inespecíficos e, em seguida, incubadas com o anticorpo policlonal anti-receptor de ocitocina (1:2000 em TTBS) durante $12 \mathrm{~h}$, a $4 \stackrel{\circ}{\circ}$. Na seqüência, as membranas foram também incubadas com o anticorpo secundário biotinilado anti-lgG $(\mathrm{H}+\mathrm{L})$ de coelho feito em cabra (1:2000 em TTBS) durante 1 hora à temperatura ambiente, e por fim, com ExtrAvidin®-peroxidase (1:2000 em TTBS).

As membranas foram então reveladas utilizando-se o kit ECL (ECL Detection Kit, Amershan, USA) para a detecção de bandas reativas por quimioluminescência, em filme fotográfico hipersensível. Para realizar o procedimento de "stripping", as membranas foram submergidas por 30 min a $50{ }^{\circ} \mathrm{C}$ em uma solução contendo $2 \%$ SDS, 100 mM mercaptoetanol e 62,5 mM Tris-HCl para a remoção dos anticorpos anteriormente encubados. Na seqüência, estas foram incubadas com anticorpo anti$\beta$-actina (Sigma, USA), feito em camundongo, na diluição 1:10.000 em TTBS overnight a $4{ }^{\circ} \mathrm{C}$ e em posteriormente, incubadas com o anticorpo secundário antiIgG de camundongo feito em cabra conjugado com peroxidase (Sigma, EUA) na diluição 1:1000 em TTBS, por 1 hora à temperatura ambiente. A revelação foi realizada da mesma forma descrita acima para o receptor de ocitocina.

Os filmes fotográficos escaneados foram submetidos a análise densitométrica utilizando-se o programa Image J (desenvolvido pelo NIH, Bethesda, USA). A semiquantificação protéica das bandas foi normatizada pela expressão protéica da $\beta$ actina na mesma amostra. Os resultados foram expressos como média \pm desvio padrão e estatisticamente analisados através do teste $t$ de Student e de Mann Whitney com o programa GraphPad Prism para Windows, versão 3.0. Adotou-se o limite de $5 \%$ para a significância estatística $(p<0,05)$. 


\section{RESULTADOS E DISCUSSÃO}

O papel da ocitocina no sistema reprodutor masculino é reconhecido pelos diversos estudos relacionados a sua expressão (mRNA) e de seu receptor em tecidos de várias espécies animais, porém não ainda não descrito em cães. Atualmente a OT tem sido utilizada no tratamento da infertilidade na reprodução humana, assim como em outras doenças incluindo as disfunções prostáticas (THACKARE; NICHOLSON; WHITTINGTON, 2006).

Os resultados da imunolocalização dos OTR e da expressão dos OTR no western blotting reforçam os estudos prévios realizados no trato reprodutor masculino demonstrando o mesmo padrão de imunomarcação.

\subsection{MORFOLOGIA DO TESTÍCULO E EPIDÍDIMO}

Na morfologia normal do testículo e epidídimo encontramos a presença de estrturas morfológicas já amplamente descritas. No testículo (Figura 1 e 2) observamos que nos túbulos seminíferos que estão envolvidos na produção dos espermatozoides que são observados na luz do túbulo. Notamos que cada túbulo seminífero é revestido pelo epitélio seminífero apresentando várias camadas de células incluindo: espermatogônias, espermatócitos, espermátide. Os espermatozoides são encontrados na luz do túbulo. Circundando os túbulos seminíferos notamos a presença das células mioepiteliais (Figura 2 A e B). NO tecido conjuntivo ao redor dos túbulos encontram-se as células intersticiais de Leydig (Figuras 1 e 2 A e B) responsáveis pela produção de testosterona. 
Figura 1 - Fotomicrografia do corte transversal de testículo de cão, H/E, x100

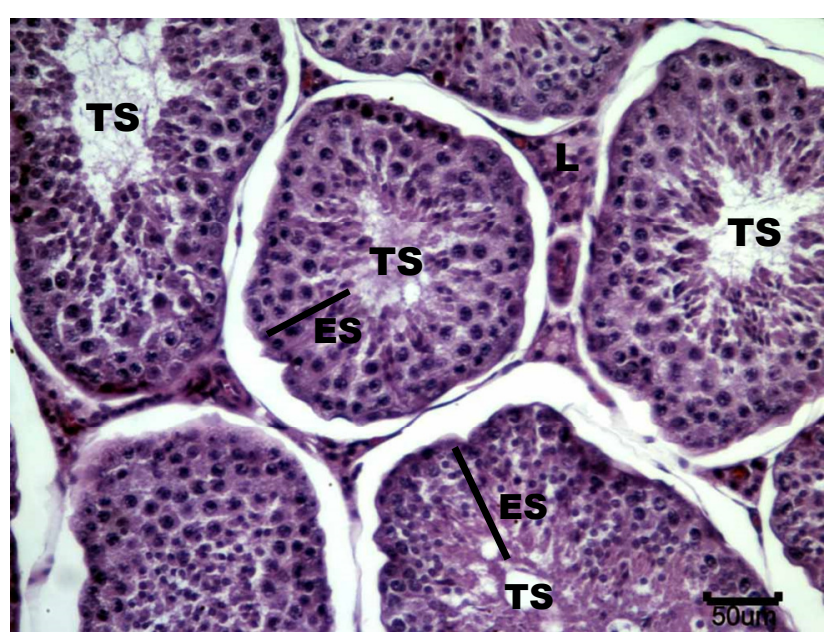

Observe a presença dos túbulos seminíferos (TS) contendo células em diferentes estágios da espermatogênese no epitélio seminífero (ES). Note a presença das células intersticias de Leydig (L) que formam aglomerados. Parafina, H/E, x100.

Figura 2 - Fotomicrografia do corte transversal de testículo de cão, H/E, x200
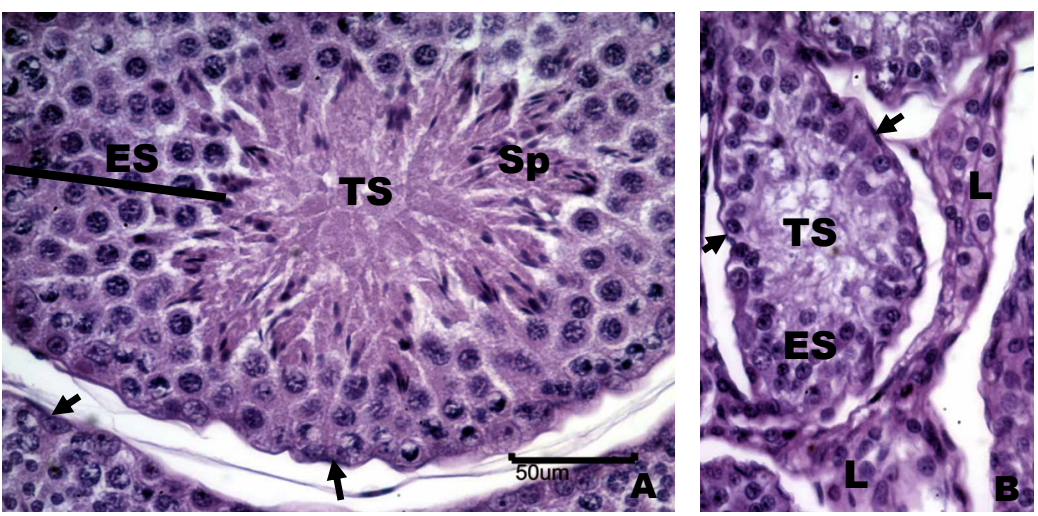

Observe em A e B a presença dos túbulos seminíferos (TS) contendo células em diferentes estágios da espermatogênese no epitélio seminífero (ES), espermatozóides (Sp), células mioepiteliais ( $\mathbf{(})$. Note a presença das células intersticias de Leydig (L) que formam aglomerados. Parafina, $\mathrm{H} / \mathrm{E}, \mathrm{x} 200$.

No epidídimo (Figura 3) observamos a presença de um epitélio pseudoestratificado colunar e o lúmen contendo numerosos espermatozóides. No trajeto pelo epidídimo os espermatozoides amadurecem. Nota-se a presença de uma túnica de músculo liso (Figura 3) disposta de maneira circular e são circundadas por tecido conjuntivo frouxo rico em vasos sanguíneos. As contrações peristálticas destas células musculares lisas permitem mover o fluido ao longo do tubo. 
Figura 3 - Fotomicrografia do corte transversal de epídídimo de cão, H/E, x100

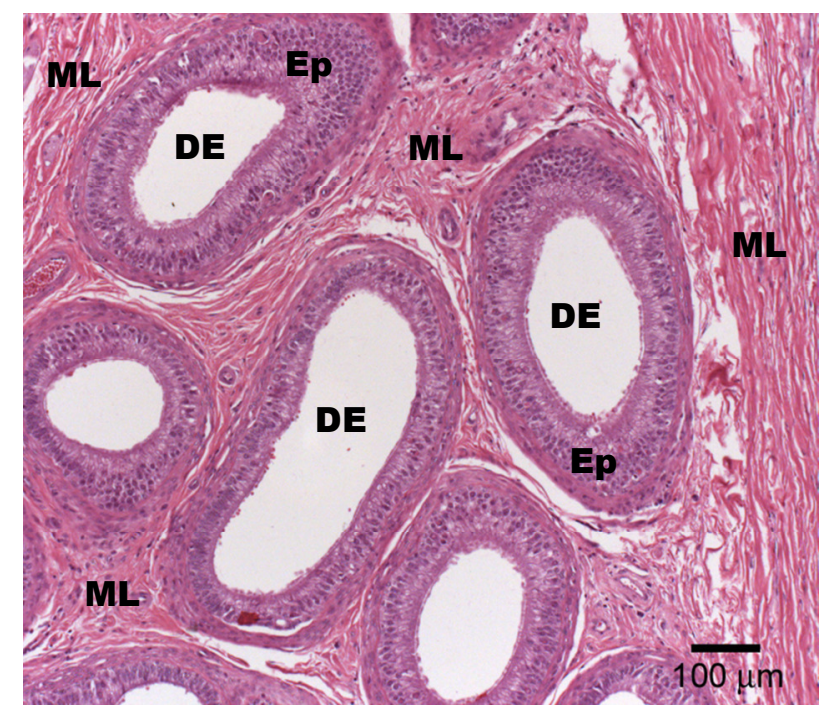

Observe a presença do epitélio pseudoestratificado colunar (Ep), ducto epididimário (DE) e da túnica muscular lisa (ML) dispostas de maneira circular. Parafina, H/E, x100.

\subsection{IMUNOISTOQUÍMICA}

Nossos resultados confirmam estudos com a OT e OTR acrescentando alguns dados principalmente no que se refere a marcação das células de Leydig e da análise qualitativa da imunomarcação e expressão dos OTR entre testículo e epidídimo. No testículo (Figuras 4 e 5) a imunomarcação foi observada nas células mioepiteliais, células musculares lisa, estroma tecidual (Figura 4) e células de Leydig (Figura 5). Estes resultados são compatíveis com os estudos que demonstraram a imunomarcação em diferentes tipos celulares tanto no testiculo como no epidídimo. Uma diferença fundamental em nossos resultados foi a imunomarcação observada nas células mioepiteliais do testículo confirmando o possível papel destas células na atividade contrátil para o transporte dos espermatozóides em direção ao epidídimo. A marcação das células de Leydig indica que exista uma relação entre a OT e os OTR e a produção de testosterona exercendo um papel na esteroidogênese. Não foi observada a marcação dos OTR nas células de Sertoli, embora muitos estudos relatem esta marcação. 
Figura 4 - Imunolocalização dos receptores de ocitocina no testículo de cão
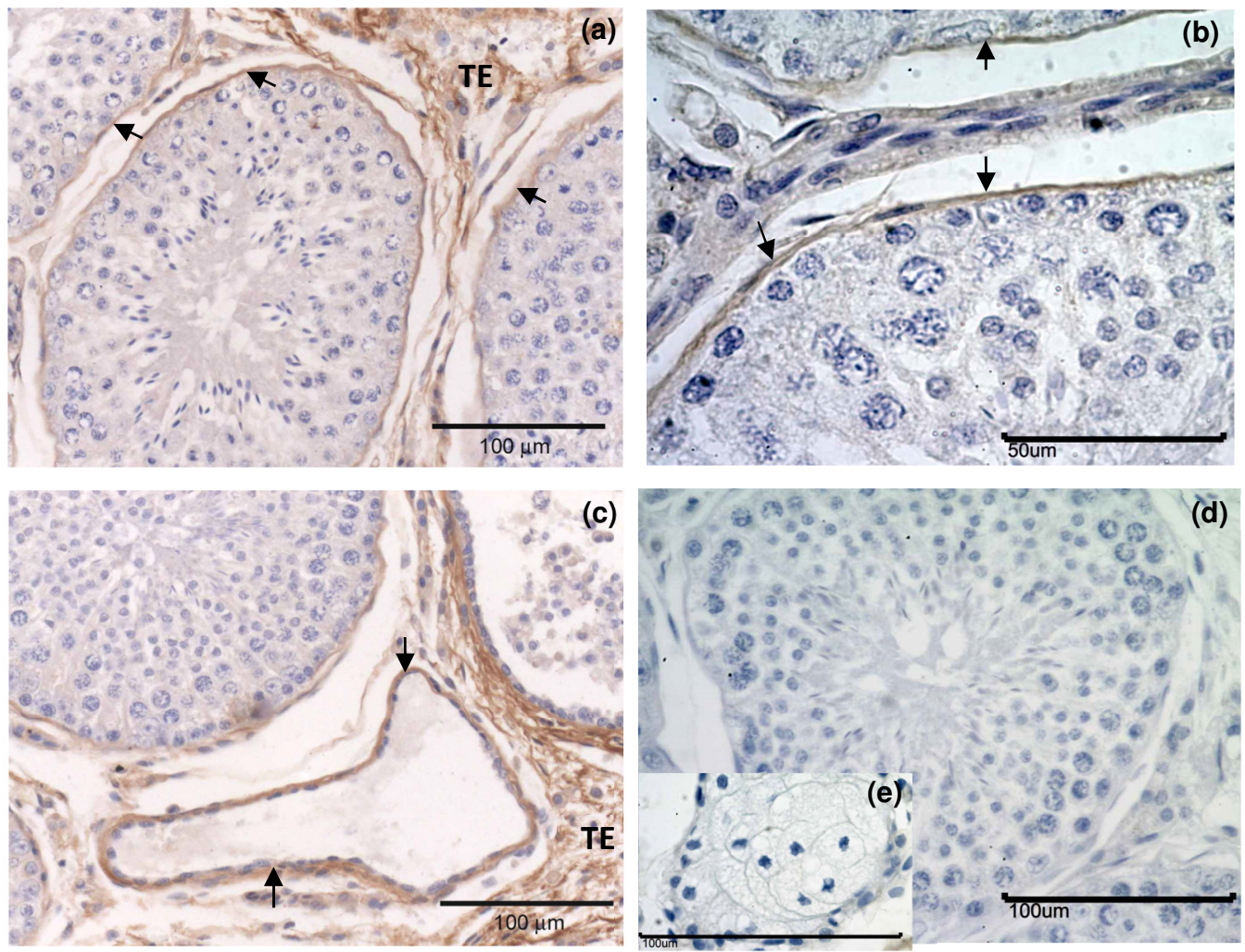

Note a imunolocalização dos receptores de OTR (a,b,c). Observe a imunomarcação (a) nas célula mioepiteliais $(\uparrow)$, estroma tecidual (TE); (b) células mioepiteliais ( $\uparrow$ ), (c) células musculares lisas $(\uparrow)$ e estroma tecidual (TE).Observe o controle negativo omitindo o anticorpo primário (d) e na glândula sebácea da pele com a presença do anticorpo primário (e). Parafina, Contracoloração com Hematoxilina de Mayer, (a,c) x100; (b,e) x400; (d) x200. 
Figura 5 - Imunolocalização dos receptores de ocitocina nas células de Leydig no testículo de cão
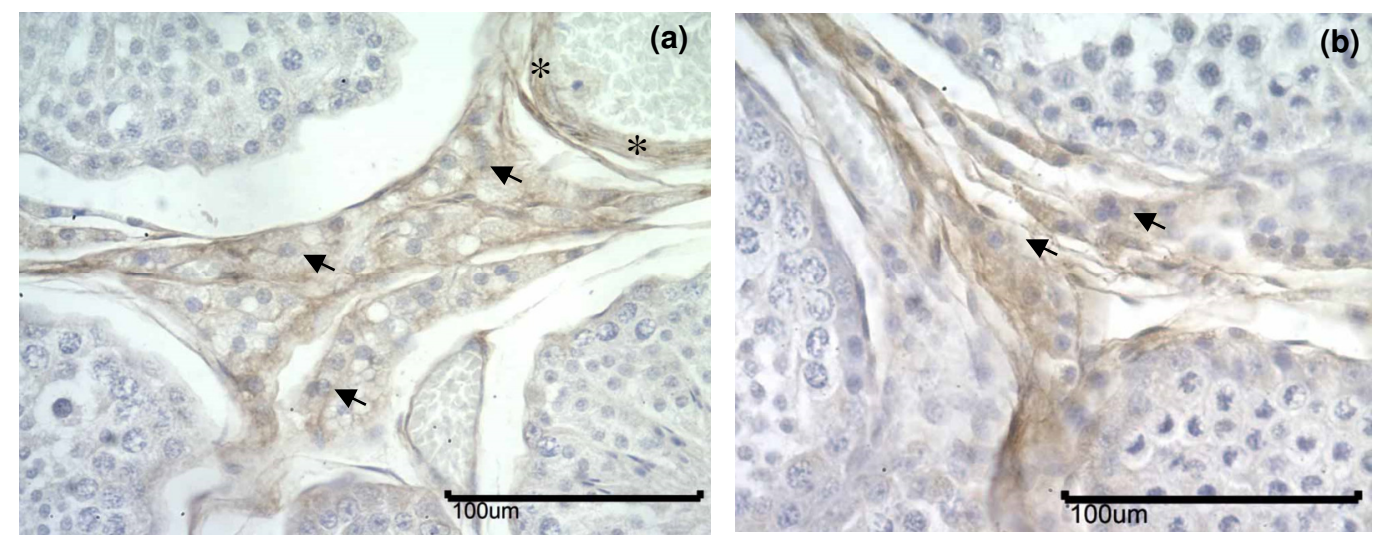

Note a imunolocalização dos receptores de OTR (a,b) nas células de Leydig $(\uparrow)$ e na musculatura lisa $\left({ }^{*}\right)$. Fotomicrografia, Parafina, Contracoloração com Hematoxilina de Mayer, x200.

A tradicional visão de que a OT é um hormônio neurohipofisário que possui ações endócrinas envolvendo o parto e lactação ganhou espaço para uma nova linha de pensamento nas últimas décadas. Atualmente sabe-se que a OT pode ser sintetizada localmente por muitos órgãos tanto no macho quanto nas fêmeas (THACKARE; NICHOLSON; WHITTINGTON, 2006). A OT exerce um papel funcional no trato reprodutor masculino possuindo receptores presentes nos tecidos dos órgãos reprodutores (WHITTINGTON et al., 2001). Neste trato a OT exerce um papel importante envolvendo funções parácrinas na contratilidade, esteroidogênese e crecimento.

A OTR presente e biologicamente ativa no epidídimo pode estar envolvida na facilitação da liberação dos espermatozóides estocados. O epidídimo é uma estrutura tubular complexa com múltiplas funções em mamíferos que incluem: maturação dos espermatozóides provenientes do testículo, estoque de espermatozóides viáveis antes da ejaculação, controle da passagem do testículo para o ducto deferente. Acredita-se que a OT inicie o processo de ejaculação agindo na população de receptores presentes de maneira diferenciada nas regiões do epidídimo e compartimentos celulares (WHITTINGTON et al., 2001).

Em nosso estudo a imunolocalização dos OTR no epidídimo de cães foi observada nas células musculares lisas (Figura 6) que se mostram intensamente 
marcadas, resultados estes compatíveis com a literatura (WHITTINGTON et al., 2001). É possível que a marcação das células musculares lisas esteja relacionada com atividade de contração, porém a marcação das células epiteliais no epidídimo não está tão bem estabelecida (FILIPPI et al., 2002). A OT e seus receptores estão presentes no trato reprodutor masculino facilitando 0 transporte dos espermatozóides na ejaculação. O entendimento dos fatores que regulam a expressão dos OTR no epidídimo permite o desenvolvimento de novas estratégias para a infertilidade em machos e novas oportunidades da utilização de contraceptivos masculinos (FILIPPI et al., 2002).

Figura 6 - Imunolocalização dos receptores de ocitocina no epidídimo de cão

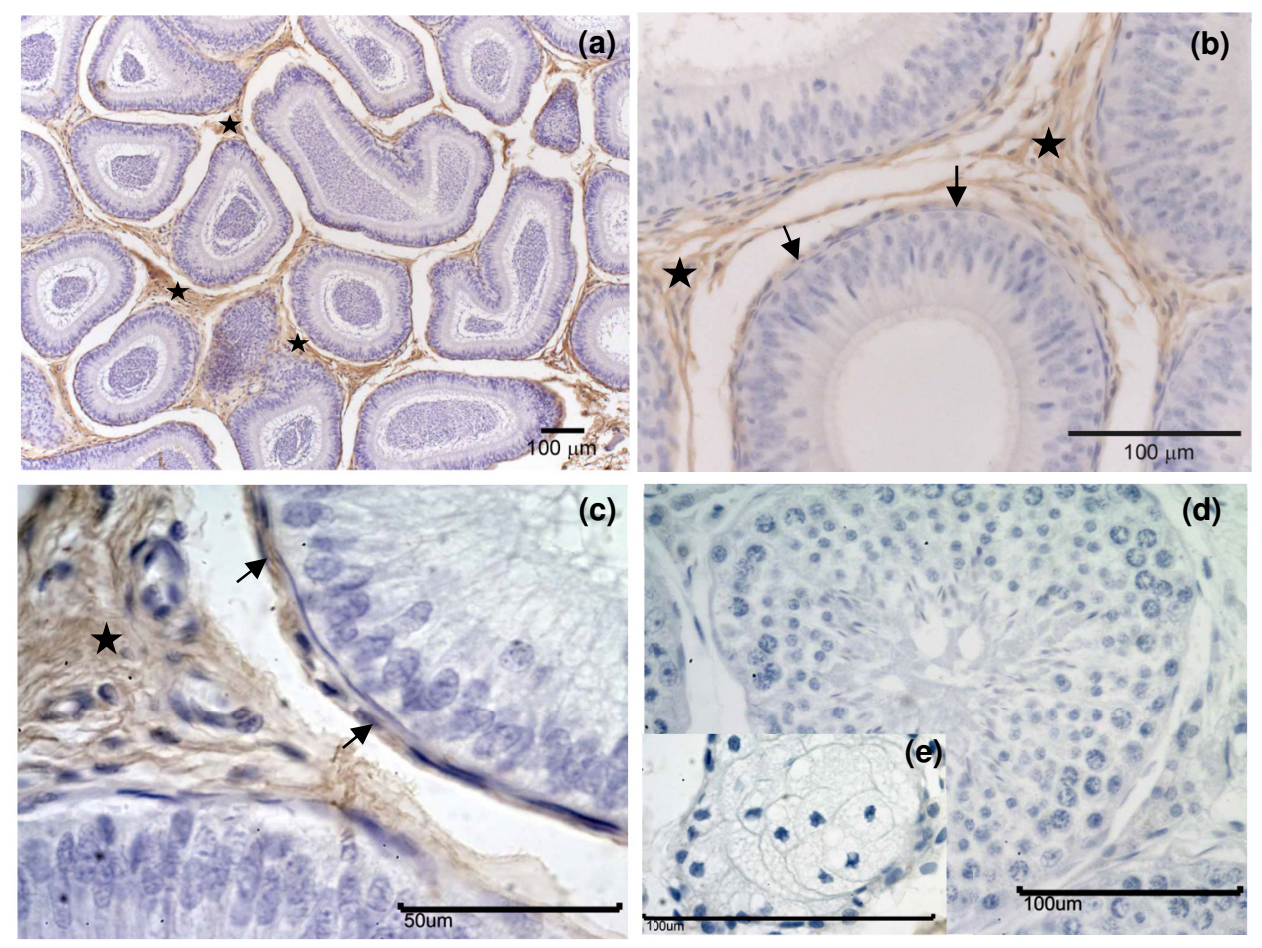

Note a imunolocalização dos receptores de OTR (a,b,c). Observe a imunomarcação $(a, b, c)$ células musculares lisas ()$,(b, c)$ nas células mioepiteliais $(\uparrow)$.Observe o controle negativo omitindo o anticorpo primário (d) e na glândula sebácea da pele com a presença do anticorpo primário (e). Fotomicrografia, Parafina, Contracoloração com Hematoxilina de Mayer, (a) x100; (b,d) x200; (c,e) x400.

Embora a OT seja muito estudada e utilizada em fêmeas, nosso estudo reforça a idéia de que há uma perspectiva para que a OT possa ser utilizada no tratamento de doenças relacionadas a infertilidade ou a outros problemas no trato reprodutor masculino possibilitando por exemplo a melhora dos parâmetros 
espermáticos no macho. Este campo de atuação parece ser promissor permitindo aos clínicos uma avaliação do uso da OT e seus antagonistas não apenas para as fêmeas como também para os machos (WHITTINGTON et al., 2001; THACKARE; NICHOLSON; WHITTINGTON, 2006).

\subsection{WESTERN BLOTTING}

Os nossos resultados do western blotting confirmaram os apresentados pela imunomarcação. Todos os animais apresentaram a expressão do receptor de ocitocina tanto no testículo quanto no epidídimo, portanto, a presença do receptor foi observada. A expressão entre testículo e epidídimo foi variada de animal para animal demonstrando a presença do receptor e a diferença entre a expressão no testículo e epidídimo. De acordo com a literatura a massa molecular do OTR varia entre $70-75 \mathrm{KDa}$ e o tamanho do OTR humano consistente com a massa molecular relatada para a glândula mamária, útero de cobaia ou âmnion de coelho (BRETON et al., 2001). No linfócito humano o OTR foi encontrado na forma de oligômero e monômero (60-70KDa) (LUI et al., 2010).

As figura 7 (a-c) mostram que ocorreu a expressão do OTR tanto no testículo como no epidídimo, demonstrando-se a presença do receptor em todas as amostras analisadas. A expressão do OTR foi variada de animal para animal notando-se que o animal 1 apresentou maior expressão proteica do receptor (a), o animal 2 não apresentou diferenças significativas e o animal 3 apresentou maior expressão no testículo (b) que no epidídimo. 
Figura 7 - Expressão protéica do receptor de ocitocina em testículos e epidídimo de cão
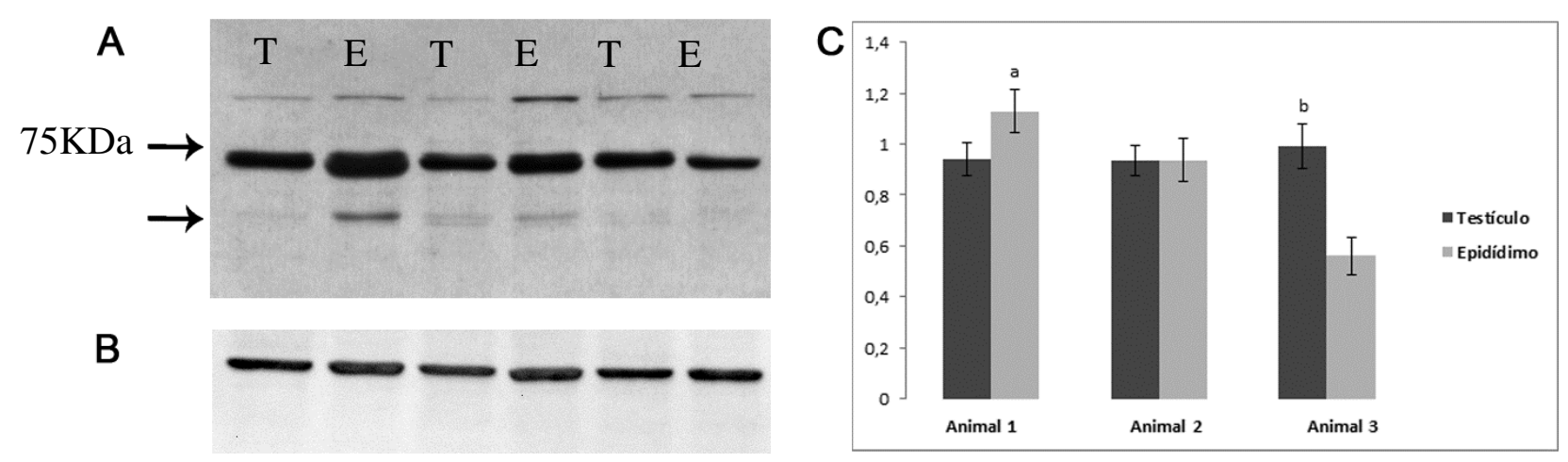

Testículo (T) e epidídimo (E) de cão em idade reprodutiva 


\section{CONCLUSÃO}

A distribuição dos receptores de OTR na imunolocalização das amostras de testículo e epidídimo analisadas e sua expressão protéica sugerem um papel importante da OT no trato reprodutivo de cães, assim como estudados em outras espécies animais. Estes resultados possibilitam abrir uma nova linha de pensamento e de pesquisa, sendo considerada uma nova alternativa para a biotecnologia da reprodução em cães no que se relaciona ao tratamento de doenças reprodutivas e da infertilidade. 


\section{REFERÊNCIAS}

AHMED, M. A.; ELOSAILY, G. M. Role of oxytocin in deceleration of early atherosclerotic inflammatory processes in adult male rats. International Journal of Clinical and Experimental Medicine, v. 4, n. 3, p. 169-178, 2011.

ANOUAR, A.; CLERGET, M. S.; DURROUX, T.; BARBERIS, C.; GERMAIN, G. Comparison of vasopressin and oxytocin receptors in the rat uterus and vascular tissue. European Journal of Pharmacology, v. 308, n. 1, p. 87-96, 1996.

BAE, S. E.; WATSON, E. D. A light microscopic and ultrastructural study on the presence and location of oxytocin in the equine endometrium. Theriogenology, $v$. 60, n. 5, p. 909-921, 2003.

BOWEN, M. T.; CARSON, D. S.; SPIRO, A.; ARNOLD, J. C.; MCGREGOR, I. S. Adolescent oxytocin exposure causes persistent reductions in anxiety and alcohol consumption and enhances sociability in rats. Plos One, v. 6, n. 11, p. e27237, 2011.

BRADFORD, M. M. A rapid and sensitive method for the quantitation of microgram quantities of protein utilizing the principle of protein-dye binding. Analytical Biochemistry, v. 72, p. 248-254, 1976.

BRETON, C.; CHELLIL, H.; KABBAJ-BENMANSOUR, M.; CARNAZZI, E.; SEYER, R.; PHALIPOU, S.; MORIN, D.; DURROUX, T.; ZINGG, H.; BARBERIS, C.; MOUILLAC, B. Direct identification of human oxytocin receptor-binding domains using a photoactivatable cyclic peptide antagonist: comparison with the human v1a vasopressin receptor. Journal of Biological Chemistry, v. 276, n. 29, p. 2693126941, 2001.

BUSNELLI, M.; SAULIERE, A.; MANNING, M.; BOUVIER, M.; GALES, C.; CHINI, B. Functional selective oxytocin-derived agonists discriminate between individual $\mathrm{g}$ protein family subtypes. Journal of Biological Chemistry, v. 287 , n. 6, p. 36173629, 2012.

CAMPBELL, D. B.; DATTA, D.; JONES, S. T.; BATEY LEE, E.; SUTCLIFFE, J. S.; HAMMOCK, E. A.; LEVITT, P. Association of oxytocin receptor (oxtr) gene variants with multiple phenotype domains of autism spectrum disorder. Journal of Neurodevelopmental Disorders, v. 3, n. 2, p. 101-112, 2011. 
CHEN, F. S.; BARTH, M. E.; JOHNSON, S. L.; GOTLIB, I. H.; JOHNSON, S. C. Oxytocin receptor (OXTR) polymorphisms and attachment in human infants.

Frontiers in Psychology, v. 2, p. 200, 2011.

CLARK, S. L.; SIMPSON, K. R.; KNOX, G. E.; GARITE, T. J. Oxytocin: new perspectives on an old drug. American Journal of Obstetrics \& Gynecology, v. 200, n. 1, p. 31-36, 2009.

DEBLON, N.; VEYRAT-DUREBEX, C.; BOURGOIN, L.; CAILLON, A.; BUSSIER, A. L.; PETROSINO, S.; PISCITELLI, F.; LEGROS, J. J.; GEENEN, V.; FOTI, M.; WAHLI, W.; DI MARZO, V.; ROHNER-JEANRENAUD, F. Mechanisms of the antiobesity effects of oxytocin in diet-induced obese rats. Plos One, v. 6, n. 9, p. e25565, 2011.

EBSTEIN, R. P.; KNAFO, A.; MANKUTA, D.; CHEW, S. H.; LAI, P. S. The contributions of oxytocin and vasopressin pathway genes to human behavior. Hormones and Behavior, v. 61, n. 3, p. 359-379, 2012.

EINSPANIER, A.; IVELL, R. Oxytocin and oxytocin receptor expression in reproductive tissues of the male marmoset monkey. Biology of Reproduction, $v$. 56, n. 2, p. 416-422, 1997.

FALCHI, L.; SCARAMUZZI, R. J. The expression of ERAlpha, OTR, CPLA(2), COX2 , and ppargamma in the cervix of the ewe during the estrous cycle.

Theriogenology, v. 79, n. 1, p. 40-47, 2013.

FELDMAN, R.; GORDON, I.; ZAGOORY-SHARON, O. The cross-generation transmission of oxytocin in humans. Hormones and Behavior, v. 58, n. 4, p. 669676, 2010.

FELDMAN, R. Oxytocin and social affiliation in humans. Hormones and Behavior, v. 61, n. 3, p. 380-391, 2012.

FILIPPI, S.; VANNELLI, G. B.; GRANCHI, S.; LUCONI, M.; CRESCIOLI, C.; MANCINA, R.; NATALI, A.; BROCCHI, S.; VIGNOZZI, L.; BENCINI, E.; NOCI, I.; LEDDA, F.; FORTI, G.; MAGGI, M. Identification, localization and functional activity of oxytocin receptors in epididymis. Molecular and Cellular Endocrinology, v. 193, n. 1-2, p. 89-100, 2002. 
FRAYNE, J.; NICHOLSON, H. D. Localization of oxytocin receptors in the human and macaque monkey male reproductive tracts: evidence for a physiological role of oxytocin in the male. Molecular Human Reproduction, v. 4, n. 6, p. 527-532, 1998.

FUCHS, A. R.; IVELL, R.; BALVERS, M.; CHANG, S. M.; FIELDS, M. J. Oxytocin receptor (OTR) gene expression and cellular localization in pregnant and parturient bovine cervix. Biology of Reproduction, v. 54, p. 275-275, 1996.

GARRISON, J. L.; MACOSKO, E. Z.; BERNSTEIN, S.; POKALA, N.; ALBRECHT, D. R.; BARGMANN, C. I. Oxytocin/vasopressin-related peptides have an ancient role in reproductive behavior. Science, v. 338, n. 6106, p. 540-543, 2012.

GIMPL, G.; FAHRENHOLZ, F. The oxytocin receptor system: structure, function, and regulation. Physiological Reviews, v. 81, n. 2, p. 629-683, 2001.

GORDON, I.; ZAGOORY-SHARON, O.; LECKMAN, J. F.; FELDMAN, R. Oxytocin, cortisol, and triadic family interactions. Physiology \& Behavior, v. 101, n. 5, p. 679684, 2010.

GORDON, I.; MARTIN, C.; FELDMAN, R.; LECKMAN, J. F. Oxytocin and social motivation. Developmental Cognitive Neuroscience, v. 1, n. 4, p. 471-493, 2011.

GUPTA, J.; RUSSELL, R.; WAYMAN, C.; HURLEY, D.; JACKSON, V. Oxytocininduced contractions within rat and rabbit ejaculatory tissues are mediated by vasopressin v1a receptors and not oxytocin receptors. British Journal of Pharmacology, v. 155, n. 1, p. 118-126, 2008.

HATAMI, L.; VALOJERDI, M. R.; MOWLA, S. J. Effects of oxytocin on cardiomyocyte differentiation from mouse embryonic stem cells. International Journal of Cardiology, v. 117, n. 1, p. 80-89, 2007.

HAWTIN, S. R.; HOWARD, H. C.; WHEATLEY, M. Identification of an extracellular segment of the oxytocin receptor providing agonist-specific binding epitopes.

Biochemical Journal, v. 354, pt. 2, p. 465-472, 2001.

HERBERT, Z.; WEIGEL, S.; SENDEMIR, E.; MARSHALL, A.; CALDWELL, J. D.; PETRUSZ, P.; PEUCKERT, C.; JIRIKOWSKI, G. F. Androgen-binding protein is coexpressed with oxytocin in the male reproductive tract. Anatomia Histologia Embryologia, v. 34, n. 5, p. 286-293, 2005. 
INABA, T.; NAKAYAMA, Y.; TANI, H.; TAMADA, H.; KAWATE, N.; SAWADA, T. Oxytocin gene expression and action in goat testis. Theriogenology, v. 52, n. 3, p. 425-434, 1999.

KIMURA, T.; ITO, Y.; EINSPANIER, A.; TOHYA, K.; NOBUNAGA, T.; TOKUGAWA, Y.; TAKEMURA, M.; KUBOTA, Y.; IVELL, R.; MATSUURA, N.; SAJI, F.; MURATA, $Y$. Expression and immunolocalization of the oxytocin receptor in human lactating and non-lactating mammary glands. Human Reproduction, v. 13, n. 9, p. 26452653, 1998.

KLARENBEEK, M.; OKKENS, A. C.; KOOISTRA, H. S.; MOL, J. A.; BEVERS, M. M.; TAVERNE, A. M. Plasma oxytocin concentrations during late pregnancy and parturition in the dog. Theriogenology, v. 68, n. 8, p. 1169-1176, 2007.

KOEHBACH, J.; STOCKNER, T.; BERGMAYR, C.; MUTTENTHALER, M.; GRUBER, C. W. Insights into the molecular evolution of oxytocin receptor ligand binding.

Biochemical Society Transactions, v. 41, n. 1, p. 197-204, 2013.

LEE, H. J.; MACBETH, A. H.; PAGANI, J. H.; YOUNG, W. S., 3RD. Oxytocin: the great facilitator of life. Progress in Neurobiology, v. 88, n. 2, p. 127-151, 2009.

LEMAIRE, W.; O'BRIEN, J. A.; BURNO, M.; CHAUDHARY, A. G.; DEAN, D. C.; WILLIAMS, P. D.; FREIDINGER, R. M.; PETTIBONE, D. J.; WILLIAMS, D. L., JR. A Nonpeptide oxytocin receptor antagonist radioligand highly selective for human receptors. European Journal of Pharmacology, v. 450, n. 1, p. 19-28, 2002.

LOPATINA, O.; INZHUTOVA, A.; SALMINA, A. B.; HIGASHIDA, H. The roles of oxytocin and cd38 in social or parental behaviors. Frontiers in Neuroscience, v. 6, p. $182,2012$.

LUI, C.; CUI, X. G.; WANG, Y. X.; YOU, Z. D.; XU, D. F. Association between neuropeptide oxytocin and male infertility. Journal of Assisted Reproduction and Genetics, v. 27, n. 9-10, p. 525-531, 2010.

MACDONALD, K. S. Sex, receptors, and attachment: a review of individual factors influencing response to oxytocin. Frontiers Neuroscience, v. 6, p. 194, 2012.

MAGON, N.; KALRA, S. The orgasmic history of oxytocin: love, lust, and labor. Indian Journal of Endocrinology and Metabolism, v. 15, p. s156-161, 2011.Supplement, 3. 
OPHIR, A. G.; GESSEL, A.; ZHENG, D. J.; PHELPS, S. M. Oxytocin receptor density is associated with male mating tactics and social monogamy. Hormones and

Behavior, v. 61, n. 3, p. 445-453, 2012.

OSTROWSKI, N. L. Oxytocin receptor MRNA expression in rat brain: implications for behavioral integration and reproductive success. Psychoneuroendocrinology, $v$. 23, n. 8, p. 989-1004, 1998.

PETERSSON, M.; LAGUMDZIJA, A.; STARK, A.; BUCHT, E. Oxytocin stimulates proliferation of human osteoblast-like cells. Peptides, v. 23, n. 6, p. 1121-1126, 2002.

PRETZER, S. D. Medical management of canine and feline dystocia.

Theriogenology, v. 70, n. 3, p. 332-336, 2008.

REVERSI, A.; CASSONI, P.; CHINI, B. Oxytocin receptor signaling in myoepithelial and cancer cells. Journal of Mammary Gland Biology and Neoplasia, v. 10, n. 3, p. 221-229, 2005.

REVERSI, A.; RIMOLDI, V.; MARROCCO, T.; CASSONI, P.; BUSSOLATI, G.; PARENTI, M.; CHINI, B. The oxytocin receptor antagonist atosiban inhibits cell growth via a "biased agonist" mechanism. Journal of Biological Chemistry, v. 280, n. 16, p. 16311-16318, 2005.

REZAPOUR, M.; BACKSTROM, T.; ULMSTEN, U. Myometrial steroid concentration and oxytocin receptor density in parturient women at term. Steroids, v. 61, n. 6, p. 338-344, 1996.

RUSSELL, J. A.; LENG, G.; DOUGLAS, A. J. The magnocellular oxytocin system, the fount of maternity: adaptations in pregnancy. Frontiers in Neuroendocrinology, v. 24, n. 1 , p. 27-61, 2003.

SENDEMIR, E.; HERBERT, Z.; SIVUKHINA, E.; ZERMANN, D. H.; ARNOLD, R.; JIRIKOWSKI, G. F. Colocalization of androgen binding protein, oxytocin receptor, caveolin 1 and proliferation marker p21 in benign prostate hyperplasia. Anatomia Histologia Embryologia, v. 37, n. 5, p. 325-331, 2008.

SHEPARD, K. N.; MICHOPOULOS, V.; TOUFEXIS, D. J.; WILSON, M. E. Genetic, epigenetic and environmental impact on sex differences in social behavior.

Physiology \& Behaviour, v. 97, n. 2, p. 157-170, 2009. 
THACKARE, H.; NICHOLSON, H. D.; WHITTINGTON, K. Oxytocin- its role in male reproduction and new potential therapeutic uses. Human Reproduction Update, v. 12, n. 4, p. 437-448, 2006.

TOPS, M.; VAN IJZENDOORN, M. H.; RIEM, M. M.; BOKSEM, M. A.; BAKERMANSKRANENBURG, M. J. Oxytocin receptor gene associated with the efficiency of social auditory processing. Front Psychiatry, v. 2, p. 60, 2011.

UVNAS-MOBERG, K.; JOHANSSON, B.; LUPOLI, B.; SVENNERSTEN-SJAUNJA, K. Oxytocin facilitates behavioural, metabolic and physiological adaptations during lactation. Applied Animal Behaviour Science, v. 72, n. 3, p. 225-234, 2001.

VIERO, C.; SHIBUYA, I.; KITAMURA, N.; VERKHRATSKY, A.; FUJIHARA, H.; KATOH, A.; UETA, Y.; ZINGG, H. H.; CHVATAL, A.; SYKOVA, E.; DAYANITHI, G. Review: oxytocin: crossing the bridge between basic science and pharmacotherapy. CNS Neuroscience \& Therapeutics, v. 16, n. 5, p. e138-156, 2010.

VRACHNIS, N.; MALAMAS, F. M.; SIFAKIS, S.; DELIGEOROGLOU, E.; ILIODROMITI, Z. The oxytocin-oxytocin receptor system and its antagonists as tocolytic agents. International Journal of Endocrinology, v. 2011, p. 350546, 2011.

WHITTINGTON, K.; ASSINDER, S. J.; PARKINSON, T.; LAPWOOD, K. R.; $\mathrm{NICHOLSON,} \mathrm{H.} \mathrm{D.} \mathrm{Function} \mathrm{and} \mathrm{localization} \mathrm{of} \mathrm{oxytocin} \mathrm{receptors} \mathrm{in} \mathrm{the}$ reproductive tissue of rams. Reproduction, v. 122, n. 2, p. 317-325, 2001.

YAMAGUCHI, E. T.; CARDOSO, M. M. S. C.; TORRES, M. L. A. Ocitocina em cesarianas: qual a melhor maneira de utilizá-la? Revista Brasileira de Anestesiologia, v. 57, p. 324-350, 2007.

YOUNG, L. J. Being human: love: neuroscience reveals all. Nature, v. 457, n. 7226, p. $148,2009$.

ZHONG, M.; BOSEMAN, M. L.; MILLENA, A. C.; KHAN, S. A. Oxytocin induces the migration of prostate cancer cells: involvement of the gi-coupled signaling pathway. Molecular Cancer Research, v. 8, n. 8, p. 1164-1172, 2010.

ZINGG, H. H. Vasopressin and oxytocin receptors. Baillieres Clinical Endocrinology and Metabolism, v. 10, n. 1, p. 75-96, 1996. 